\author{
UNIVERSIDADE DE SÃO PAULO \\ FACULDADE DE MEDICINA DE RIBEIRÃO PRETO \\ DEPARTAMENTO DE PUERICULTURA E PEDIATRIA
}

Emiliana Ribeiro Darrigo

Estudo da Associação do Tecido Adiposo Medular Ósseo, Massa Óssea e a Expressão do Receptor tipo 1 dos IGFs em Crianças e Adolescentes Obesos 


\section{Estudo da Associação do Tecido Adiposo Medular Ósseo, Massa Óssea e a Expressão do Receptor tipo 1 dos IGFs em Crianças e Adolescentes Obesos}

Dissertação apresentada à Faculdade de Medicina de Ribeirão Preto da Universidade de São Paulo para obtenção do Título de Mestre em Ciências.

Área de concentração:

Saúde da Criança e do Adolescente, Investigação em Pediatria.

Orientador:

Prof. Dr. Carlos Eduardo Martinelli Junior

Ribeirão Preto 
Autorizo a reprodução e divulgação total ou parcial deste trabalho, por qualquer meio convencional ou eletrônico, para fins de estudo e pesquisa, desde que citada a fonte.

\section{FICHA CATALOGRÁFICA}

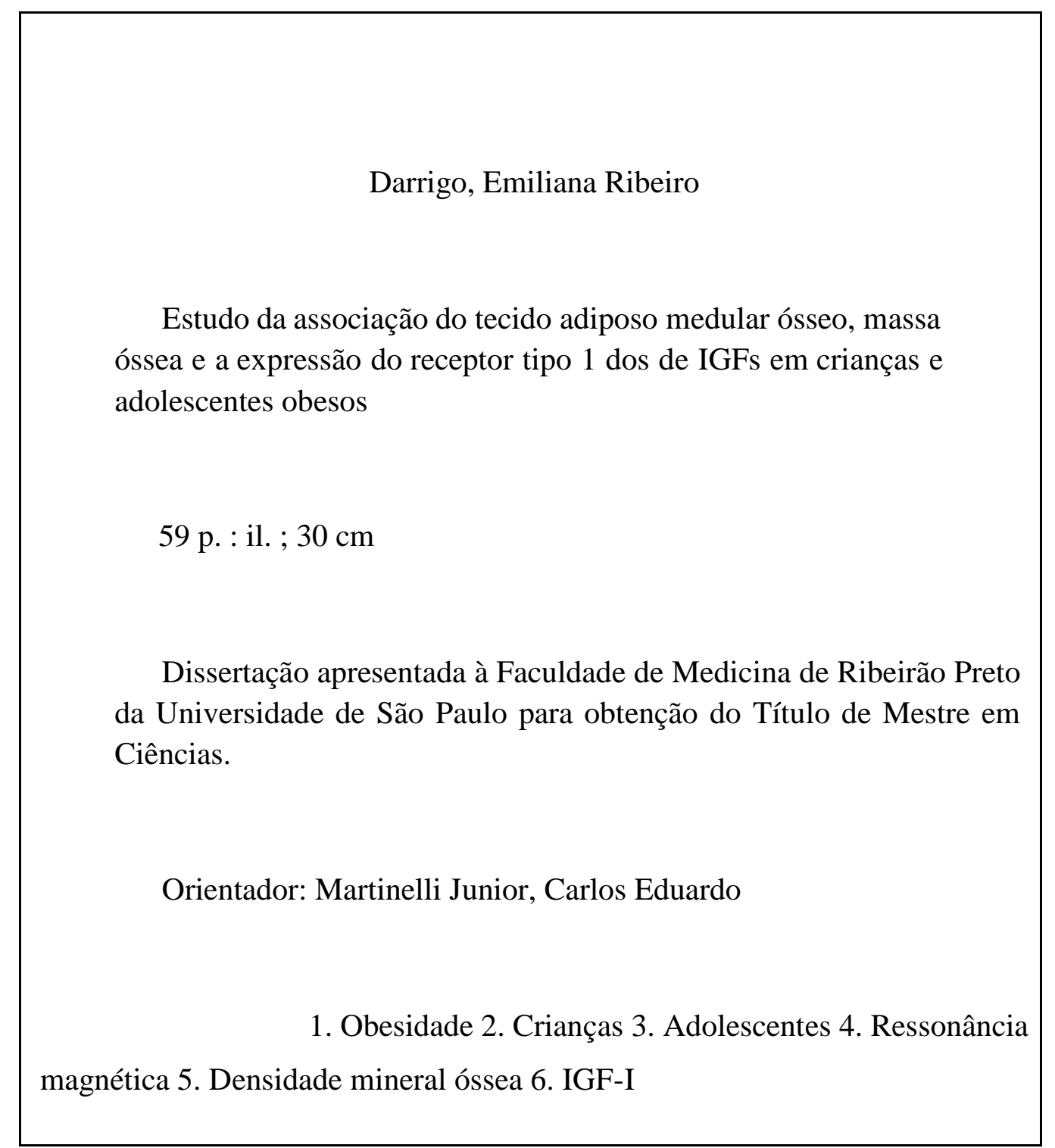


DEDICATÓRIA 


\section{DEDICATÓRIA}

À Deus por ter concluído essa dissertação com saúde.

Às crianças e adolescentes, por serem o maior incentivo para a realização desse projeto.

Aos meus pais, Arquimedes e Vera, que mesmo de longe, sempre acreditaram no meu potencial. Sem eles não teria realizado o sonho de ser médica. Cada esforço valeu a pena e hoje posso entregá-los esse projeto.

À Lidianne e Arquimedes Junior, que por serem meus irmãos, são as únicas pessoas que sabem perfeitamente as dificuldades que enfrentei para me formar em medicina, fazer as residências médicas em Pediatria e Endocrinologia e agora buscar esse título de Mestre em Ciências .

Ao Luiz Guilherme Darrigo Junior, meu esposo, pelo incentivo à pesquisa desde a época de faculdade e pelo exemplo que é como médico.

Aos meus dois filhos em especial, por terem participado intensamente desde o início, mesmo que de dentro de mim. Felipe acompanhou todas as disciplinas nos primeiros 9 meses da pós-graduação e Helena pôde assistir de camarote os últimos 9 meses até a defesa. Foi muito difícil chegar até aqui, diante de tantos cuidados que os dois me exigiam como mãe, mas certamente essa dissertação será orgulho para eles quando crescerem. 


\section{AGRADECIMENTOS}

Ao Prof. Dr, Carlos Eduardo Martinelli Junior, pela confiança desde a época de residência médica. Pelo cuidado que sempre teve comigo, além de ter sido algumas vezes um ombro amigo. Agradeço aos vários momentos em que precisou fazer papel de pai, me oferecendo oportunidades para crescer como pessoa e como profissional.

Ao Prof. Dr. Francisco José Albuquerque de Paula, pelo incentivo à pesquisa e pela colaboração indispensável para a realização desta dissertação. Agradeço também pelos conselhos quase diários e por me introduzir ao extraordinário universo que é o metabolismo ósseo.

À Profa. Dra. Soraya Sader, pela colaboração e incentivo à essa pesquisa. Pela forma como me acolheu desde que cheguei em Ribeirão Preto e pela amizade que construímos.

Ao Prof. Dr.Ivan Savioli Ferraz pelo apoio durante a realização desse projeto, principalmente durante o período da disciplina Programa de Aperfeiçoamento em Ensino (PAE). Me fez amar ainda mais a puericultura e a pediatria.

Aos outros docentes do Departamento de Endocrinologia do HC-FMRP-USP Prof. Dr. Ayrton Moreira, Prof. Dr. Sonir Antonini, Prof. Dr. Rafael Liberatore Junior, Profa. Dra. Margaret de Castro, Profa. Dra Paula Elias, Prof. Dra Maria Cristina Foss pelos exemplos de dedicação à pesquisa.

Aos médicos assistentes do Departamento de Endocrinologia da Criança e do Adolescente, Patrícia Volpon Atique, Rodrigo José Custódio e Mariana Sarti de Paula agradeço pelos ensinamentos constantes e principalmente pela amizade de vocês.

Aos médicos Thaís Ache e Alexander Engelberg, pela importante ajuda para obter os indivíduos controle desse trabalho. 
À equipe do Centro de Radiologia do HC-FMRP-USP, Prof. Dr. Marcello Henrique Nogueira Barbosa, Prof. Dr. Antônio Carlos Santos, Prof. Dr. Jorge Elias Junior, Prof. Dr. Carlos Ernesto Garrido Salmon, Rodrigo Pessini, Luciana, Adriana, Maria célia, Maria do Rosário, Rita de Cássia, Karina, Marina, Wagner pela ajuda na realização dos exames de imagem.

À equipe do Laboratório de Endocrinologia e Metabolismo Ósseo do HC-FMRP-USP, Marta Nakao, Helen Alves de Oliveira, Fernanda Orsolini, Maria Yoshiko Matuyama, Priscila dias Pereira, Sebastião Lazaro,Luciana Tabajara, Adriana Lelis, Maria Augusta Viana Alencar, Sérgio Luchini e em especial Iana Mizumukai de Araújo pela ajuda em cada detalhe deste trabalho, além da amizade que ficará para sempre.

À Veridiana Kill Suazo e Rosane Queiroz pela ajuda nas dosagens laboratoriais realizadas no laboratório de Pediatria-Biologia Molecular do HC-FMRP-USP e pela amizade que cresceu ainda mais.

Às secretárias do Departamento de Puericultura e Pediatria do HC-FMRP-USP, Vera, Dulcides, Fernanda, Sandra e Cláudia por me auxiliarem quantas vezes foi preciso.

Às crianças que participaram dessa pesquisa, pela paciência e colaboração em realizar os exames.

Ao Conselho Nacional de Pesquisa (CNPQ) pelo auxílio financeiro. 
Darrigo ER. Associação do tecido adiposo medular ósseo, massa óssea e a expressão do receptor tipo 1 dos IGFs em crianças e adolescentes obesos.

Resumo 2017.73p. Dissertação (Mestrado) - Faculdade de Medicina de Ribeirão Preto, Universidade de São Paulo, Ribeirão Preto, 2017.

O tecido adiposo e ósseo tem uma íntima relação, desde a origem comum nas células tronco estromais derivadas da medula óssea. Sabe-se que o peso corporal tem estreita correlação com a massa óssea em seres humanos. Porém, ainda não é claro qual componente do peso corporal tem maior influência sobre o ganho de massa óssea e sobre a adiposidade na medula óssea, visto que tanto indivíduos com baixo peso, quanto os obesos, apresentam altas taxas de fraturas. O objetivo deste trabalho foi comparar crianças e adolescentes obesos e eutróficos em relação a composição óssea, adiposidade da medula óssea em coluna lombar (L3), expressão do Receptor tipo 1 de IGF (IGF1R) e concentrações séricas de IGF-I e buscar correlação entre estas variáveis. Para tanto foram avaliados crianças e adolescentes de 10 a 17 anos, divididos em grupo controle e grupo obeso. Esses grupos foram submetidos a avaliação antropométrica, densitometria óssea de coluna lombar e corpo total e ressonância magnética de coluna lombar e abdome total, além de dosagens séricas de parâmetros bioquímicos e hormonais. Os pacientes do grupo obeso apresentaram associação positiva da densidade mineral óssea tanto com massa gorda quanto com massa magra, enquanto que o grupo controle apresentou associação positiva da densidade mineral óssea apenas com a massa gorda. Não houve diferença entre os grupos quanto a adiposidade da medula óssea, nem quanto aos valores de IGF-I, IGFBP3 e expressão do gene do IGF1R. 
Darrigo ER. Association of bone marrow adipose tissue, bone mass, and type 1 IGF receptor expression in obese children and adolescents. 2017.73p. Dissertação (Mestrado) - Faculdade de Medicina de Ribeirão Preto, Abstract $\quad$ Universidade de São Paulo, Ribeirão Preto, 2017.

The adipose and bone tissue has an intimate relationship, from the common origin in stromal stem cells derived from the bone marrow. It is known that body weight has a close correlation with bone mass in humans. However, it is still unclear which component of body weight has a greater influence on bone mass gain and adiposity in the bone marrow, since both individuals with low weight and obese have high fracture rates. The objective of this study was to compare obese and eutrophic children and adolescents in relation to bone composition, bone marrow adiposity in the lumbar spine (L3), expression of IGF type 1 receptor (IGF1R) and serum concentrations of IGF-I and to seek correlation between these variables. For this, children and adolescents between 10 and 17 years old were divided into control and obese groups. These groups were submitted to anthropometric evaluation, bone densitometry of the lumbar spine and total body and lumbar spine and total abdominal magnetic resonance, in addition to serum levels of biochemical and hormonal parameters. The patients in the obese group had a positive association of bone mineral density with both fat mass and lean mass while the control group showed a positive association of bone mineral density with fat mass only. There was no difference between the groups regarding bone marrow adiposity, nor regarding IGF-I, IGFBP3 and IGF1R gene expression.

Key words: obesity, children, adolescents, magnetic resonance imaging, bone mineral density, IGF-I 


\section{LISTA DE FIGURAS}

Figura 1: Sistema RANK-RANKL-OPG

Figura 2: L3 Voxel no centro do corpo vertebral L3 (em laranja) em espectroscopia por ressonância magnética (no alto, à esquerda) e respectivo espectro da medula óssea vertebral com dois picos distintos (à direita). As áreas sob a curva evidenciam quantidades de água e gordura na vértebra.

Figura 3: RM de abdome, corte transversal, do ambiente do software Display. Área marcada em vermelho foi usada para cálculo de adiposidade subcutânea, enquanto que a área em verde foi usada para cálculo de adiposidade visceral. .36

Figura 4: Regiões de interesse selecionadas em imagem de RM de abdome para cálculo de gordura hepática..

Figura 5: DMO de coluna lombar (L1-L4) e L3 por Z score e Z score corrigido. 43

Figura 6: DMO de coluna lombar (L1-L4) areal $\left(\mathrm{g} / \mathrm{cm}^{2}\right)$ e volumétrica $\left(\mathrm{g} / \mathrm{cm}^{3}\right)$

Figura 7: Porcentagem de AMO entre os dois grupos . .45

Figura 8: Expressão do RNA do gene do IGF1R $\left(2^{-\Delta \Delta C T}\right)$ nos dois grupos. 46

Figura 9: Valores de IGF-I e IGFBP-3 nos dois grupos .47 


\section{LISTA DE TABELAS}

Tabela 1: Idade,peso, altura e IMC. Valores expressos em média \pm DP e mediana (entre parênteses) .39

Tabela 2: Dados de marcadores bioquímicos e lipidograma. Valores expressos em média \pm DP e mediana (entre parênteses). 40

Tabela 3: Dados do metabolismo do cálcio e CTX. Valores expressos em média \pm DP e mediana (entre parênteses).

Tabela 4: Composição corporal mediante densitometria óssea. Valores expressos em média \pm DP e mediana (entre parênteses).

Tabela 5: Dados da densitometria óssea referentes a DMO. Valores expressos em média \pm DP e mediana (entre parênteses) 42

Tabela 6: Dados da ressonância magnética de coluna lombar e abdome referentes a AMO, área subcutânea, área visceral e gordura hepática.Valores expressos em média \pm DP e mediana (entre parênteses) 45

Tabela 7: Dados referentes ao sistema IGF: IGF-I, IGFBP3 e expressão do gene do IGF1R. Valores expressos Em média \pm DP e mediana (entre parênteses)

Tabela 8: Correlação entre variáveis relativas à massa óssea e adiposidade da medula óssea nos indivíduos do grupo controle. Valores expressos coeficiente de correlação (r).

Tabela 9: Correlação entre variáveis relativas à massa óssea e adiposidade da medula óssea nos indivíduos do grupo obeso. Valores expressos em coeficiente de correlação (r).

Tabela 10: Correlação entre variáveis relativas à massa óssea, adiposidade da medula óssea, valores séricos de IGF-I, IGFBP-3 e expressão do RNA do IGF1R nos indivíduos do grupo controle. Valores expressos coeficiente de correlação (r).

Tabela 11: Correlação entre variáveis relativas à massa óssea, adiposidade da medula óssea, valores séricos de IGF-I, IGFBP-3 e expressão do RNA do IGF1R nos indivíduosdo grupo obeso. Valores expressos coeficiente de correlação (r).

Tabela 12: Correlação entre variáveis relativas à massa óssea, adiposidade da medula óssea, valores séricos de cálcio total, fósforo inorgânico, fosfatase alcalina e CTX nos indivíduos do grupo controle. Valores expressos coeficiente de correlação (r).

Tabela 13: Correlação entre variáveis relativas à massa óssea, adiposidade da medula óssea, valores séricos De cálcio total, fósforo inorgânico, fosfatase alcalina e CTX nos indivíduos do grupo obeso. Valores expressos coeficiente de correlação (r).

Tabela 14: Correlação entre variáveis relativas à massa óssea, adiposidade da medula óssea e composição corporal nos indivíduos do grupo controle. Valores expressos coeficiente de correlação (r).

Tabela 15: Correlação entre variáveis relativas à massa óssea, adiposidade da medula óssea e composição corporal nos indivíduos do grupo obeso. Valores expressos coeficiente de correlação (r). 
Tabela 16: Correlação entre variáveis relativas à massa óssea, adiposidade da medula óssea, área subcutânea, gordura visceral e hepática nos indivíduos do grupo controle. Valores expressos em coeficiente de correlação (r)

Tabela 17: Correlação entre variáveis relativas à massa óssea, adiposidade da medula óssea, área subcutânea, gordura visceral e hepática nos indivíduos do grupo obeso. Valores expressos em coeficiente de correlação (r). .52

Tabela 18: Modelo de regressão linear: associação da AMO, IGF1R, IGF-I e IMC com DMO em L3. 


\section{LISTA DE ABREVIATURAS E SIGLAS}

\begin{tabular}{|c|c|}
\hline $25(\mathrm{OH}) \mathrm{D}$ & 25-hidroxivitamina D \\
\hline $\mathrm{cm}$ & Centímetros \\
\hline CTx & Telopeptídeo do colágeno tipo I \\
\hline $\mathrm{dL}$ & Decilitro \\
\hline DMO & Densidade mineral óssea \\
\hline DP & Desvio padrão \\
\hline DXA & Densitometria óssea \\
\hline FMRP & Faculdade de Medicina de Ribeirão Preto \\
\hline GH & Hormônio de crescimento \\
\hline $\mathrm{HC}$ & Hospital das Clínicas de Ribeirão Preto \\
\hline HDL & Lipoproteína de alta densidade \\
\hline IGF-I & Fator de crescimento semelhante à insulina \\
\hline IGFBP3 & Proteína transportadora tipo 3 do IGF \\
\hline IMC & Índice de massa corporal \\
\hline $\mathrm{Kg}$ & Quilogramas \\
\hline $\mathrm{L}$ & Litros \\
\hline L3 & Terceira vértebra da coluna lombar \\
\hline LDL & Lipoproteína de baixa densidade \\
\hline $\mathrm{m}$ & Metros \\
\hline $\mathrm{mg}$ & Miligramas \\
\hline $\mathrm{mL}$ & Mililitros \\
\hline $\mathrm{Mm}$ & Milímetros \\
\hline $\begin{array}{l}\text { MS } \\
\text { U Unidade }\end{array}$ & Milisegundos \\
\hline ng & Nanogramas \\
\hline
\end{tabular}


RANK Receptor ativador do Fator nuclear Kappa B ligante

RANKL

Fator nuclear Kappa B ligante

TE

Tempo de eco

TGO

Transaminase glutâmica oxalacética

TGP

Transaminase glutâmica pirúvica

TR

Tempo de repetição

$\mathrm{U}$

Unidade

USP

Universidade de São Paulo 


\section{SUMÁRIO}

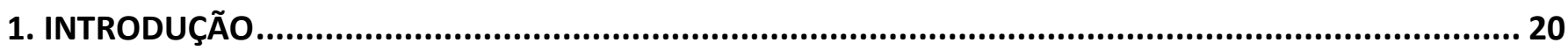

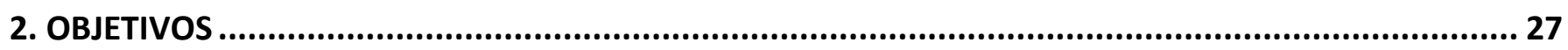

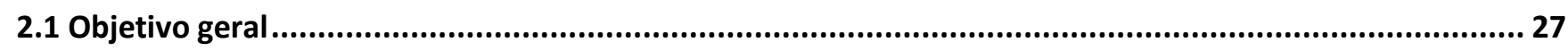

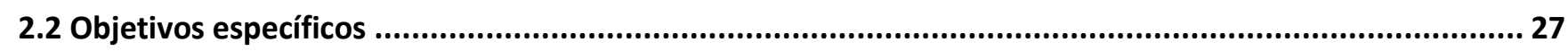

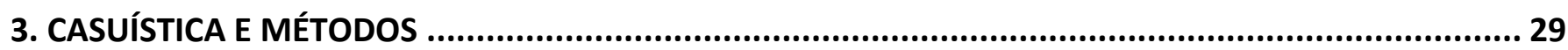

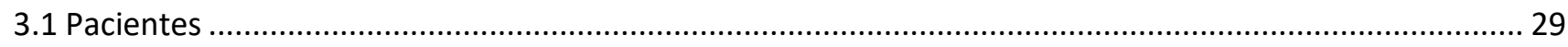

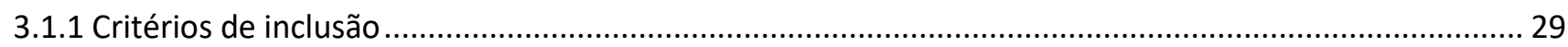

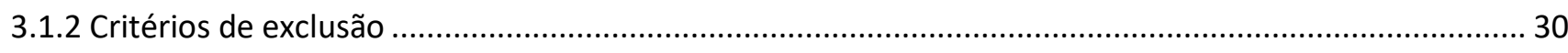

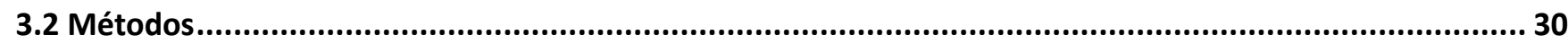

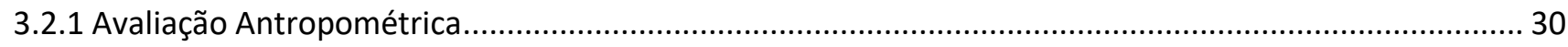

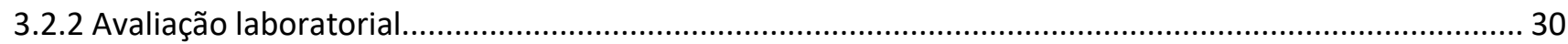

3.2.2.1 Processamento das amotras de sangue periférico ….......................................................................... 31

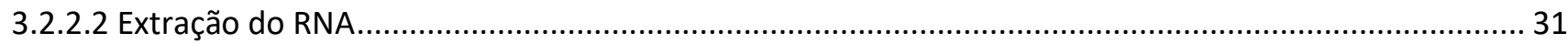

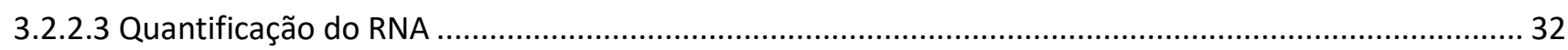

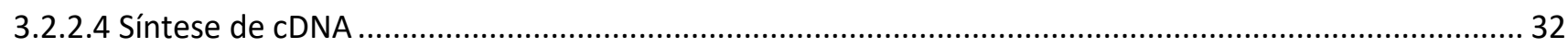

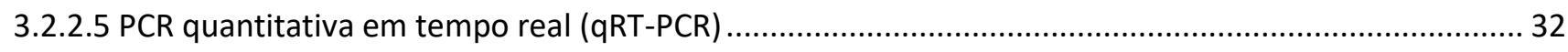

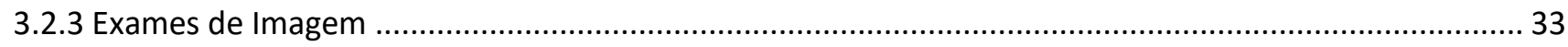

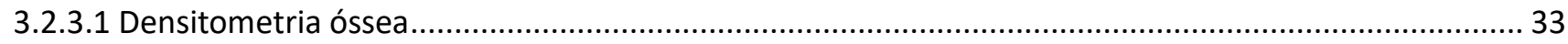

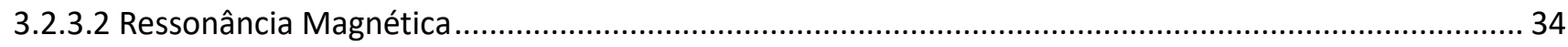

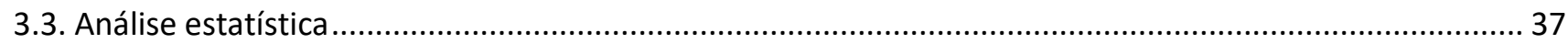

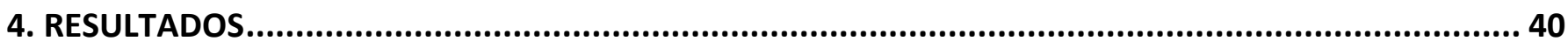

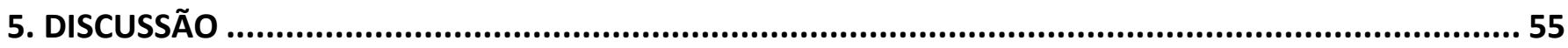

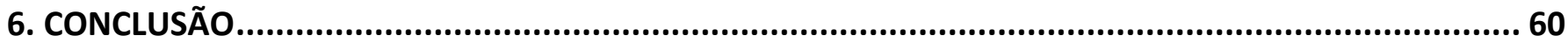

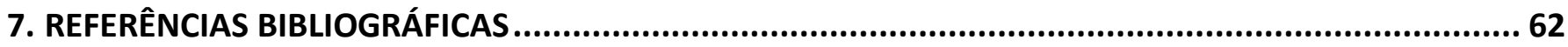


INTRODUÇÃO 


\section{INTRODUÇÃO}

Os ossos possuem um elevado grau de rigidez, a qual é requerida para que o esqueleto dê sustentação ao corpo e proteção a órgãos mais sensíveis. Além disso, são apoio para os músculos, aumentando a força do movimento proporcionado pela contração muscular (Campos et al.,2003). O tecido ósseo é constituído de células (osteoblastos, osteoclastos e osteócitos) matriz inorgânica (minerais cálcio e fósforo) e matriz orgânica, composta principalmente de colágeno, dos quais o tipo I corresponde a $95 \%$.

Os osteoblastos são responsáveis pela síntese da porção orgânica da matriz óssea, enquanto os osteoclastos são responsáveis pela reabsorção óssea. A combinação de atividade de osteoblastos e osteoclastos permite que os ossos sejam modelados durante o crescimento e remodelados continuamente. Já os osteócitos parecem ser os sensores bioquímicos e mecânicos, apresentando uma rede extensa de canalículos de comunicação intercelular e tendo papel crucial na regulação da atividade de remodelação óssea.

A formação óssea sofre interferência de diversos fatores, dentre eles idade, raça, sexo, alterações hormonais, nutricionais e mecânicos (Cassidy, 1999). Já a remodelação óssea consiste em um processo fisiológico contínuo e complexo, o qual garante a conservação e renovação da matriz óssea. Esse processo é altamente regulado pela interação entre as células ósseas, hormônios sistêmicos, citoquinas, fatores de crescimento e mediadores inflamatórios (de Paula et al., 2013).

Nos últimos anos houve um avanço significativo no conhecimento da biologia esquelética. $\mathrm{O}$ reconhecimento do sistema operacional RANK, RANK-L e osteoprotegerina é um exemplo emblemático deste processo de avanço que tem mostrado existir uma complexa rede de comunicação celular entre as diversas células que compõem o tecido ósseo. Os osteoclastos expressam em sua superfície os receptores de ativação do fator nuclear kappa B (RANK).

A superfície dos osteoblastos expressa o ligante do RANK (RANK-L) e a osteoprotegerina (OPG), proteína que pertence aos membros da família de receptores para fator de necrose tumoral. Após a ligação do RANK-L ao RANK, há ativação de sinais de diferenciação de pré-osteoclastos em osteoclastos, definindo assim, o principal sinal intercelular de promoção de lise óssea. Por outro lado, a OPG ao ligar-se ao RANK-L, inibe sua interação com o RANK, sendo portanto um importante fator moderador da osteoclastogênese e da atividade osteoclástica.(figura 1) O RANK-L é estimulado por hormônios calciotrópicos como paratormônio $(\mathrm{PTH})$, peptídeo relacionado ao $\mathrm{PTH}, 1,25(\mathrm{OH})_{2} \mathrm{D}$, assim como interleucinas (IL-1.IL-11,IL-17), TNF-alfa e prostaglandinas E2 (PGE2) (Kohli et al., 2011). 


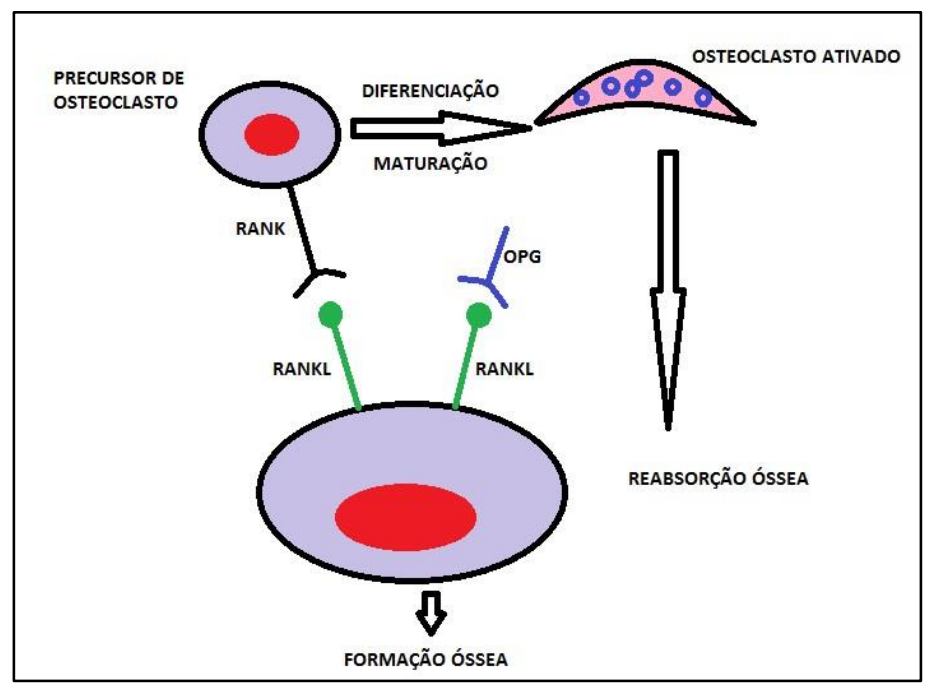

Figura 1: Sistema RANK-RANKL-OPG

Os processos de formação e reabsorção óssea variam nas diferentes fases da vida. Durante a infância, há maior formação do que reabsorção óssea. A remodelação óssea é muito intensa, principalmente nos dois primeiros anos de vida e durante a puberdade, quando os esteróides gonadais passam a ser produzidos. A deposição mineral óssea durante esse período relaciona-se a mudanças da composição corporal, maturação sexual e crescimento (Zemel, 2013).

Na vida pós-natal a aquisição de massa óssea inicia-se ao nascimento, alcançando sua maior velocidade de ganho durante a puberdade. Mesmo após atingida a estatura final, há persistência do processo de desenvolvimento de massa óssea. Esta fase é chamada de transição ou consolidação, período que se inicia no final da puberdade e termina com a maturidade óssea do adulto. O pico de massa óssea, caracterizado pelo máximo de massa óssea adquirido durante a fase de maturação corporal, ocorre durante a terceira década de vida e subsequentemente ocorre uma fase de relativa estabilidade que vai até o final da quarta década, quando começa a diminuir naturalmente. O pico de massa óssea é peculiar de cada indivíduo e sofre influência de diversos fatores como herança genética, fatores hormonais, atividade física, nutrição, bem como ocorrência de doença e seu tratamento.

O pico de massa óssea é tão importante na determinação da saúde esquelética futura que diversos grupos de pesquisa consideram a osteoporose uma doença pediátrica com repercussão geriátrica. Desta forma, é importante garantir condições adequadas para o desenvolvimento do potencial genético de massa óssea de crianças e adolescentes, a fim de evitar suscetibilidades a fraturas na vida adulta, como consequência de osteoporose (Van der Sluis et al., 2001; Borelli, 2000)

A osteoporose é definida como uma doença metabólica esquelética, caracterizada por diminuição da massa óssea e alteração da microarquitetura do tecido ósseo. Em consequência disso, surgem a 
fragilidade óssea e o risco aumentado de fraturas. A osteoporose reflete um desequilíbrio entre a ação dos osteoclastos e osteoblastos, a qual, em última instância, leva a um balanço negativo do processo de remodelação óssea. A herança genética tem sido sugerida em estudos familiais como sendo responsável por cerca de $85 \%$ da variação da massa óssea, sugerindo que a osteoporose é uma doença com forte componente hereditário e possivelmente de caráter poligênico (Zmuda et al., 1999).

Pessoas do sexo feminino são mais susceptíveis à osteoporose, pois apresentam menor ganho de massa óssea durante o desenvolvimento e ainda mostram perda óssea significativa durante a menopausa ( Riggs et al., 1986). A diminuição da produção de estrogênio, que ocorre em mulheres após a menopausa, tem sido apontada como um dos principais fatores de risco para o desenvolvimento de osteoporose. Existem claras evidências na literatura de que os hormônios sexuais são de extrema relevância para a aquisição de massa óssea e para o crescimento ósseo. Sendo assim, pessoas com perda de fonte estrogênica, como ooforectomia ou menopausa, apresentam perda óssea acelerada, evoluindo mais rapidamente para osteoporose (Amadei et al., 2006).

O estrogênio tem ação protetora no tecido ósseo, atuando diretamente em seus receptores em osteoblastos. Eriksen et al em 1988 foram os primeiros a detectarem receptores estrogênicos funcionais em células osteoblásticas extraídas de tecido ósseo humano (Eriksen et al., 1988). Os receptores de estrogênio estão presentes em diversos tecidos. A resposta tecidual ao hormônio é proporcional ao número de receptores locais, sendo que o estrogênio se liga ao receptor de forma reversível e com alta afinidade e especificidade (Turner et al.,1994). Após a ligação de estrogênio aos receptores de osteoblastos, ocorre ambos, inibição da liberação de fatores estimuladores e aumento da atividade dos fatores inibidores de osteoclastos. Estudos prévios mostram que a ação estrogênica no tecido ósseo se deve em parte à redução das interleucinas (IL-1, IL4, TGF-B), diminuição da produção de RANKL e aumento de osteoprotegerina no microambiente ósseo (Raiz, 2005). Assim, no hipoestrogenismo o aumento de interleucinas e RANKL são fatores promotores de reabsorção óssea (Amadei et al, 2006).

Diversos estudos mostram existir relação positiva entre peso corporal e densidade óssea. No entanto, os dados são controversos quanto ao componente da composição corporal que tem maior impacto sobre a massa óssea. Alguns grupos defendem que a massa muscular é o elemento mais importante, enquanto outros indicam ser a massa gorda. (Reid et al ,1994; Bredella et al ,2011). Adicionalmente, estudos recentes sugerem que o papel do tecido adiposo sobre a massa óssea é muito mais complexa do que se acreditava antes. Talvez mais importante do que o conteúdo global de adiposidade seja o nicho de deposição de tecido adiposo. Além disto, o conteúdo de adiposidade da medula óssea (AMO) passou a ser também alvo de intenso interesse de estudo do seu papel na determinação do desenvolvimento e manutenção da massa óssea (Reid, 2010). 
A obesidade se tornou problema de saúde pública ao redor do mundo, sendo atualmente considerada um importante fator de risco para diversas doenças, incluindo o diabetes mellitus, hipertensão arterial, doença cardiovascular, doença osteoarticular e vários tipos de câncer. Por outro lado, o peso guarda forte associação positiva com a massa óssea (Reid,2010), implicando em baixa taxa de diagnóstico de osteoporose em obesos quando se utiliza a densitometria óssea como meio diagnóstico. No entanto, nos últimos anos diversos estudos mostraram que a obesidade não parece ter efeito protetor quanto ao surgimento de fratura (Premaor et al., 2014).

Em crianças e adolescentes, é consenso o aumento significativo da obesidade, inclusive em menores de cinco anos de idade, determinando a possibilidade de complicações tanto na infância, quanto na vida adulta (Cunningham et al., 2014 ; Cheung et al., 2016). Infelizmente, o tratamento clínico conservador, que envolve a abordagem multidisciplinar de mudança de hábitos, apresenta baixa taxa de sucesso. Quanto menor a faixa etária, mais difícil se torna o manejo dessa doença, visto a dificuldade de modificação de hábitos, menor entendimento da criança quanto aos danos da obesidade e a necessidade de se preservar ritmo adequado de crescimento (Mello et al., 2004). Diante deste cenário, tem surgido grande interesse na investigação de fatores de risco para fratura em indivíduos obesos.

Outro aspecto relevante é a distribuição de gordura corporal. A obesidade visceral é claramente um fator de maior desestabilização metabólica e de geração de resistência à insulina e inflamação crônica moderada. Além disto, o complexo quadro de resistência à insulina e inflamação crônica associado à obesidade centrípeta é fortemente associado à doença cardiovascular, a principal causa de morte no mundo ocidental (Tsatsoulis et al., 2013)

Diversos estudos tem encontrado associação negativa da adiposidade visceral com a massa óssea. Dentre os mecanismos envolvidos nesse processo estão a inflamação aumentada, menor quantidade de vitamina D e desregulação do eixo GH-IGF-I (hormônio do crescimento- fator de crescimento insulina símile tipo 1) (Bredella et al., 2014).

Os hormônios que compõem o sistema GH-IGF-I, associados a herança genética, formam o grupo de fatores que influenciam diretamente o crescimento. A glândula pituitária anterior ou adeno-hipófise, localiza-se na fossa hipofisária do osso esfenoide na base do crânio. Esta glândula é responsável pela produção do GH, através das células somatotróficas, que constituem 30-40\% das células da adeno-hipófise. Essas células são estimuladas pelo GHRH (hormônio hipotalâmico liberador do GH), somatostatina e, em menor intensidade pela ghrelina. O GH é constituído, na sua maioria, por 198 aminoácidos em uma cadeia 
única, com peso molecular $22 \mathrm{kDa}$. Apenas 5- $10 \%$ do $\mathrm{GH}$ circulante tem peso molecular $20 \mathrm{kDa}$ (Rosenfeld et al., 2002).

A secreção do GH ocorre em pulsos, com meia -vida de aproximadamente 20 minutos. Esses pulsos ocorrem, principalmente, no início das fases III e IV do sono, variando de 6 -10 pulsos em 24 horas. A idade é um fator influenciador da amplitude dos pulsos e da massa de GH secretada. Assim, durante o período da puberdade, há maior secreção deste hormônio, que tem seus valores diminuídos progressivamente ao longo da vida adulta. A ação do GH é mediante receptor específico (GHR), que apresenta domínio extracelular, porção transmembrânica e domínio citoplasmático. O GH é o principal regulador fisiológico da produção hepática de IGF-I sérico. (Martinelli et al., 2005; Rosenfeld et al., 2002).

Os IGFs (IGF-I e IGF-II) são peptídeos semelhantes à insulina, que exercem influência sobre o metabolismo intermediário, proliferação, crescimento e diferenciação celular (Martinelli et al., 2008). Os genes que codificam os IGFs estão localizados no braço longo do cromossomo 12 (IGFl) e braço curto do cromossomo 11 (IGF2). A maioria dos órgãos e tecidos do organismo produzem IGFs, não existindo local para armazenamento do mesmo. Sendo assim, eles são secretados na circulação sanguínea a medida em que são produzidos, exercendo forte ação endócrina, parácrina e autócrina (Jogren et al., 1999).

A ação dos IGFs ocorre mediante interação com receptores de IGF tipo 1 (IGF1R) e tipo 2 (IGF2R) localizados na membrana celular. Esses receptores também apresentam estruturas semelhantes aos receptor de insulina (Martinelli et al., 2005 ; Rosenfeld et al., 2002). Os IGFs estão na circulação, em sua maioria, por meio de um complexo ternário formado por uma proteína transportadora (IGFBP) e uma subunidade proteica ácido-lábil (ALS) (Baxter et al., 1989). Assim como os IGFs, as IGFBPs são produzidas em diversos órgãos e tecidos do organismo, sendo a IGFBP3, a mais abundante dentre as 6 existentes. Além de aumentarem o tempo de circulação dos IGFs, as IGFBPs também exercem funções autócrinas, parácrinas e endócrinas (Jones et al., 1995). Ao longo da infância observa-se aumento gradual das concentrações de IGF-I e IGFBPs, com pico durante a puberdade e declínio na idade adulta, alcançando níveis superiores aos encontrados na infância (Underwood et al.,1985).

Sabe-se que o sistema GH-IGF-I é um importante regulador da homeostase óssea, porém o papel desse sistema na diferenciação de células-tronco mesenquimais ainda é complexo. A quantidade de IGF-I ósseo depende da produção local de IGF-I pelos osteoblastos corticais e trabeculares e também do IGF-I circulante (Lopes et al.,2006). O IGF-I é um dos fatores de crescimento mais abundantes no desenvolvimento ósseo, exercendo papel importante na manutenção da massa óssea por meio do reforço da matrix óssea e inibição da degradação óssea. (Giustina et al.,2008). 
A integridade do eixo GH-IGF é fundamental para o desenvolvimento saudável do ser humano (Marui et al., 2002). Os hormônios que compõem esse eixo, em especial o IGF-I, associados ao padrão genético de cada indivíduo, influenciam diretamente o crescimento. O período da infância e adolescência é considerado o mais importante para aquisição de massa óssea e apesar de haver mudanças endócrinometabólicas envolvidas no processo de ossificação, pouco se sabe sobre a gordura óssea e massa óssea em crianças e adolescentes com obesidade, assim como a participação dos sistema GH-IGF neste processo (Cobayashi et al., 2005). Estudo recente conduzido por Ricco et al em 2017, mostrou que o IGF1R é expresso em maior quantidade em crianças obesas (Ricco et al., 2017). 


\section{OBJETIVOS}

\subsection{Objetivo geral}

Comparar crianças e adolescentes obesos e eutróficos em relação a composição óssea, adiposidade da medula óssea em coluna lombar (L3), expressão do gene do receptor tipo 1 de IGF (IGF1R) e concentrações séricas de IGF-I e buscar correlação entre estas variáveis.

\subsection{Objetivos específicos}

- Buscar correlação entre massa óssea, AMO e expressão do gene do IGF1R.

- Buscar correlação entre massa óssea, AMO e concentrações de IGF-I e IGFBP-3.

- Buscar correlação entre massa óssea, AMO e composição corporal, massa gorda visceral e hepática. 
CASUÍSTICA E MÉTODOS 


\section{CASUÍSTICA E MÉTODOS}

\subsection{Indivíduos}

Partimos de uma amostra de conveniência inicial de 60 indivíduos de oito anos de idade completos a dezoito anos incompletos que concordaram em participar. Ao longo do estudo esta amostra foi reduzida para os 30 pacientes aqui apresentados, como mostra o fluxograma em anexo (anexo 1).

Foi realizado um estudo transversal com crianças e adolescentes na faixa etária de dez a dezessete anos de idade, totalizando 30 indivíduos, de ambos os sexos. O total de indivíduos foi separado em dois grupos, sendo 15 indivíduos eutróficos para compor o grupo controle (GC), e 15 para o grupo obeso (GO).

Todos os indivíduos foram abordados pessoalmente pela pesquisadora e convidados a participar deste estudo quando atendidos no Ambulatório de Puericultura e Pediatria do centro Comunitário da Vila lobato e no Ambulatório de Obesidade na Infância e na Adolescência do HC-FMRP-USP. Ambos locais de recrutamentos localizados na cidade de Ribeirão Preto-SP.

Após abordagem e aceitação em participar do estudo, as crianças e adolescentes, assim como seus responsáveis, receberam e devolveram o Termo de Assentimento e Termo de Consentimento Livre e Esclarecido (TCLE), respectivamente assinados. (Anexo 2)

O projeto foi encaminhado e aprovado pelo Comitê de Ética em Pesquisa do HC-FMRP-USP em 31 de agosto de 2015. (Processo $n^{0} 4673 / 2015$ ). (Anexo 3)

\subsubsection{Critérios de inclusão}

- Indivíduos com diagnóstico de obesidade prímária ,cujos índice de massa corporal (IMC) apresentavam-se com valores acima do Escore $\mathrm{z}+2$ da curva da OMS para idade e sexo. ( WHO Growth reference data for 5-19 years,2007).

- Indivíduos eutróficos, com IMC entre o Escore z - 2 e +1 da curva da OMS. (WHO Growth reference data for 5-19 years, 2007) 


\subsubsection{Critérios de exclusão}

- Indivíduos que apresentaram qualquer intercorrência após inclusão no projeto, que sabidamente alterasse os resultados dos exames, tanto laboratorias quanto de imagens.

- Indivíduos que não desejaram continuar a participação no estudo.

\subsection{Métodos}

\subsubsection{Avaliação Antropométrica}

Todos os indivíduos deste estudo foram submetidos à avaliação antropométrica pelo mesmo examinador (pesquisadora), por meio de aferição do peso em quilogramas $(\mathrm{Kg})$ e estatura em centímetros (cm), conforme técnica preconizada por Frisancho em 1990. Para verificação do peso, os indivíduos foram posicionados de maneira ereta sobre a balança digital, utilizando apenas roupas leves. A estatura foi medida em estadiômetro vertical fixado à parede, onde os pacientes se posicionavam descalços, pés unidos e calcanhares encostados na parede, em posição ereta, com olhar fixo no horizonte, sem extensão do pescoço. Foram obtidas duas alturas em centímetros e calculada a média. Estes dados foram utilizados para o cálculo do IMC, definido como massa corporal em quilos, dividida pela estatura em metros elevada ao quadrado $\left(\mathrm{Kg} / \mathrm{m}^{2}\right)$.

\subsubsection{Avaliação laboratorial}

Todos os indivíduos incluídos neste estudo foram submetidos a coleta sanguínea uma única vez, realizado pela pesquisadora. Estas coletas ocorreram em intervalo não superior a 6 meses da realização o exame de RM, sempre no período da manhã, em jejum de 12 horas, de todos os indivíduos do GC e GO, em ocasião coincidente com outras coletas previamente agendadas de rotina. No GO, os exames para o estudo foram colhidos no mesmo momento que o perfil lipídico e glicemia de jejum realizados periodicamente. Já nos indivíduos do GC, os exames foram colhidos no mesmo momento que o hemograma, também realizado periodicamente para esses pacientes. Sendo assim, não foi necessário submeter os indivíduos a mais de uma coleta sanguínea para esse estudo.

Foram retirados dos indivíduos em torno de 10 a $15 \mathrm{ml}$ de sangue periférico em membro superior direito ou esquerdo. Estas amostras sanguíneas foram utilizadas para determinar os seguintes parâmetros 
bioquímicos e hormonais: glicose plasmática de jejum, cálcio sérico total, fósforo inorgânico, fosfatase alcalina, perfil lipídico, albumina,telopeptideo carboxiterminal do colágeno tipo I (CTx), IGF-I, IGFBP3 e expressão do gene do IGF1R.

Os valores de CTx foram determinados por eletroquimioluminescência (Elecsys, Roche) e os valores de IGF-I e IGFBP3 pelo método de quimioluminescência (Immulite 2000, Siemens, Los Angeles, CA, USA).

Os valores de glicose plasmática de jejum, cálcio sérico total, fósforo inorgânico, fosfatase alcalina, perfil lipídico e albumina foram determinados no Laboratório Central do HC-FMRP-USP, em aparelho analisador bioquímico automático (KONELAB 60i, Wiener, Thermo Clinical Labsystem ou Ruukintie, Espoo, Finlândia), assim como dosagens séricas de transaminase glutâmico-oxalacética (TGO) , transaminase glutâmico-pirúvica (TGP), uréia e creatinina , os quais, foram colhidos para afastar acometimento hepático e/ou renal.

Alíquotas de soro foram armazenadas a $-80^{\circ} \mathrm{C}$ para futuras mensurações de outros parâmetros,tais como osteocalcina $(\mathrm{OC}), 25(\mathrm{OH}) \mathrm{D}, \mathrm{PTH}$ intacto, leptina e adiponectina, insulina, leptina e adiponectina.

A expressão do IGF1R foi realizada mediante extração e quantificação de RNA, com posterior síntese de cDNA e realização da Reação em Cadeia de Polimerase em tempo real (qRT-PCR), como descrito a seguir:

\subsubsection{Processamentodas amotras de sangue periférico}

As amostras de sangue periférico foram submetidas a um processo de hemolise utilizando Cloreto de amonio e Bicarbonato de amonia na proporção 9:1, respectivamente. Após hemolise, as amostras foram centrifugadas a $3.000 \mathrm{rpm}$ por 15 minutos a $4^{\circ} \mathrm{C}$. O pellet de células foi ressuspendido em $250 \mathrm{ul}$ de tampão PBS e foi adicionado 750ul de TRIzol®LS Reagent e o conteúdo foi homogeneizado e estocado a $-80^{\circ} \mathrm{C}$ para posterior extração de RNA total.

\subsubsection{Extração do RNA}

O RNA total foi isolado dos pellets de leucócitos utilizando TRIzol@LS Reagent (Invitrogen Inc, Carlsbad, CA, EUA). As amostras foram descongeladas, homogeneizadas e incubadas em temperatura ambiente por cinco minutos para permitir a completa dissociação dos complexos nucleoproteicos. Foram adicionados $200 \mathrm{uL}$ de clorofórmio (Merck, AL) e homogeneizadas vigorosamente por quinze segundos, incubadas por 3 minutos em temperatura ambiente e centrifugadas a $13.000 x g$ por 15 minutos a $4^{\circ} \mathrm{C}$. 
Neste sistema, o RNA permanece exclusivamente na fase aquosa incolor, que foi retirado com cuidado, evitando a interfase, e transferido para um novo tubo ao qual foram adicionados $500 \mathrm{uL}$ de álcool isopropílico $100 \%$ (Merck, AL) e homogeneizado por inversão. As amostras foram incubadas overnight a $-20^{\circ} \mathrm{C}$ e após esse tempo, submetidas a centrifugação por 20 minutos a $13.000 \mathrm{rpm}$ a $4^{\circ} \mathrm{C}$, o sobrenadante foi desprezado e o precipitado foi lavado com $1 \mathrm{~mL}$ de etanol $75 \%$ em água tratada com dietilpirocarbonato (DEPC) 0,1\% (ambos Merck, AL) por duas vezes. O sobrenadante foi desprezado e o precipitado de RNA foi seco à temperatura ambiente; ressuspenso em $30 \mathrm{uL}$ de água DEPC $0,1 \%$ e estocados a $-80^{\circ} \mathrm{C}$.

\subsubsection{Quantificação do RNA}

A concentração e pureza do RNA total foi avaliada pelo aparelho NanoDrop Spectrophotometer (Thermo Scientific, DE, EUA). O padrão de qualidade para o teste de pureza do RNA é dado pela razão dos valores de absorbância $A_{260} / A_{280}$ e deve ser igual a 2,0. Um outro indicador de pureza é a relação $\mathrm{A}_{260} / \mathrm{A}_{230}$, que deve ser de 2,2. Uma razão $\mathrm{A}_{260} / \mathrm{A}_{230}$ inferior a 1,8 indica níveis significativos de contaminantes orgânicos, tais como hidratos de carbono, peptídeos, fenol e TRIzol, que absorvem luz a 230 $\mathrm{nm}$.

\subsubsection{Síntese de cDNA}

Para a análise de expressão por qRT-PCR as amostras de RNA total foram utilizadas para a síntese do DNA complementar (cDNA). O RNA total (500 ng) foi reversamente transcrito com os reagentes do kit High Capacity cDNA Reverse Transcription (Applied Biosystems, Fostes City, CA, EUA, \#Cat. 4368814) padronizado para uma reação: 2,5 uL de 10X RT Buffer, 0,5 uL de 25X dNTP Mix (100 mM), $0,63 \mathrm{uL}$ de RNAse Out, 1,25 uL de MultiScribe ${ }^{\circledR}$ Reverse Transcriptase (50 U/ $\left.\mu \mathrm{L}\right)$ (MultiScribe ${ }^{\mathrm{TM}}$ MuLV) e 2,5 uL de primer randômico (oligonucleotídeo iniciador). O volume final da reação foi equalizado com água ultra pura para $25 \mathrm{uL}$.

\subsubsection{PCR quantitativa em tempo real (qRT-PCR)}

Cada amostra foi amplificada em duplicata, sendo consideradas para análise as amostras cujo valor de desvio padrão não excedeu 0,5. Foi utilizado o método de quantificação relativa, o qual sinaliza a mudança de expressão do gene alvo em relação ao calibrador escolhido. Para expressão do gene IGF1R foi utilizada sonda TaqMan (HS_000000) e como controle endógeno foi utilizado a média geométrica da expressão do genes GUSB (HS_0000000) e B2M (HS_0000000) obtidas para cada amostra. A expressão 
de uma amostra controle foi utilizada como calibrador e a quantificação relativa foi calculada pela fórmula $2^{-\triangle \Delta C T}$ (Livak \& Schmittgen, 2001).

\subsubsection{Exames de Imagem}

Todos os exames de imagem foram realizados no Centro de Imagens do HCFMRP-USP. Os indivíduos incluídos neste estudo realizaram exames de densitometria óssea de corpo total e coluna lombar (L1-L4), além de ressonância magnética de abdome total e de coluna lombar (L1-L4), agendados de acordo com a conveniência do indivíduo em estudo e disponibilidade de horários no Centro de Imagens do HCFMRP-USP.

\subsubsection{Densitometria óssea}

Foram realizados 36 exames de densitometria óssea de coluna lombar (L1-L4) e corpo total por meio da técnica de raio-x de dupla energia (DXA) em aparelho da marca Hologic (Discovery Wi, QDR series, Waltham, MA, USA). Os resultados foram expressos em conteúdo mineral ósseo (CMO) em gramas, densidade mineral óssea (DMO) em grama/ $\mathrm{cm}^{2}$ e Z-score para idade e sexo.

Posteriormente os resultados da DMO em coluna lombar (L1-L4) e L3 foram ajustados para g/cm ${ }^{3}$ por meio da fórmula matemática proposta por Carter et al, onde DMOc é densidade mineral óssea corrigida, $\alpha$ é densidade mineral óssea areal em g/cm2 e $\beta$ é área óssea em $\mathrm{cm}^{2}{ }^{20}$

$\mathrm{DMOc}=\alpha \sqrt{\beta}$

A avaliação da composição corporal foi feita para obtenção dos dados de gordura corporal total em gramas, massa magra sem conteúdo ósseo em gramas, porcentagem de massa gorda, massa gorda e massa magra em tronco em gramas e porcentagem de gordura em tronco.

Ressalta-se que a quantidade de radiação a que os adolescentes foram expostos são consideradas seguras e sem prejuízo para sua saúde atual e futura. 


\subsubsection{Ressonância Magnética}

Foram realizados 36 exames de ressonância magnética de abdome e coluna lombar (L1-L4), por meio do aparelho 1,5 Tesla (Philips Medical System;modelo ACHIEVA) ) utilizando bobina phasedarray para a região lombar

A adiposidade da medula óssea em coluna lombar (L3) foi referida por meio de espectroscopia de $\mathrm{H}^{1}$ aplicada à ressonância magnética, onde imagens ponderadas em T2 adquiridas em orientação sagital foram utilizadas como localizadoras para a espectroscopia (TE: 120ms, gap: 4,4mm, echo-trainlenght: 19, TR: 3900ms, espessura do corte: $4 \mathrm{~mm}$, flip angle: $45^{\circ}$ ).

Um voxel cúbico de 1,5 cm de lado posicionado sobre o corpo vertebral L3 serviu como volume de interesse para aplicação da técnica PRESS, com 8 medidas, sem supressão do sinal da água, TR=2000ms e múltiplos valores de TE=40/60/80ms. A duração desta aquisição foi de 1 minuto. Os dados foram processados com o software LCmodel (PROVENCHER, 1993) com o qual foi calculada a fração de gordura, a partir da área sob a curva do sinal na região de 1,3 ppm e 4,7 ppm, relacionada com a concentração de gordura e água, respectivamente. A duração da aquisição da espectroscopia foi de aproximadamente 1 minuto. O ambiente visual do programa LC Model está representado na (Figura 2).

O valor relatado no presente estudo foi a fração gordura/água+gordura ou simplesmente adiposidade da medula óssea, sendo a concentração de água (pico na região de 4,7 ppm) igualmente corrigida ante o efeito de relaxação transversal. 


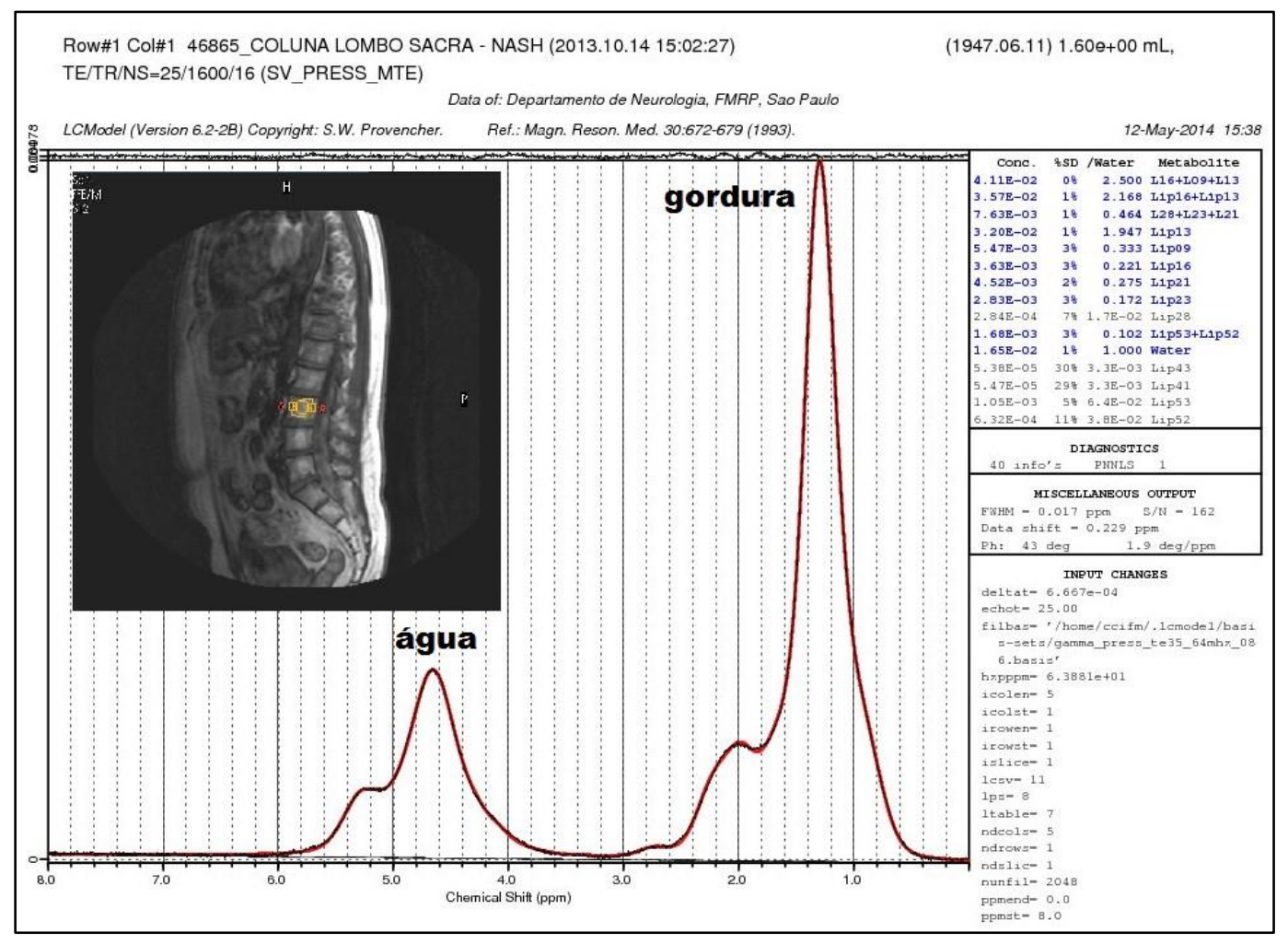

Figura 2: L3 Voxel no centro do corpo vertebral L3 (em laranja) em espectroscopia por ressonância magnética (no alto, à esquerda) e respectivo espectro da medula óssea vertebral com dois picos distintos (à direita). As áreas sob a curva evidenciam quantidades de água e gordura na vértebra. Imagens cedidas pelo serviço de Radiologia do HC-FMRP-USP.

A análise de adiposidade visceral, subcutânea e hepática foi realizada no software Display (Brain Imaging Center of the Montreal Neurological Institute). Para análise da adiposidade visceral e subcutânea foi utilizado o corte axial ao nível da cicatriz umbilical obtido na sequencia $\mathrm{T} 1$, com realização de segmentação manual da adiposidade subcutânea e visceral, com obtenção da área em mm²(figura 3). A área da gordura abdominal total foi considerada a soma das áreas da adiposidade visceral e subcutânea no mesmo corte. O cálculo da quantidade de gordura nestas áreas é feito pela obtenção do número e do tamanho dos voxels $(\mathrm{mm})$ segmentados. 


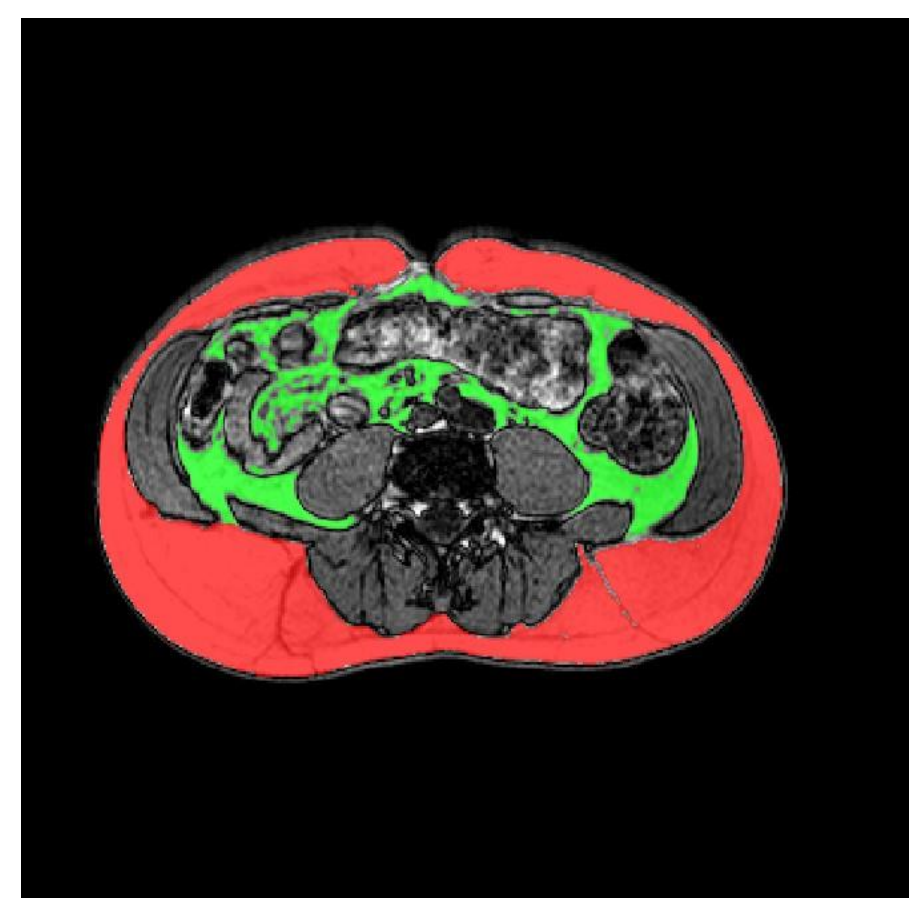

Figura 3: RM de abdome, corte transversal, do ambiente do software Display. Área marcada em vermelho foi usada para cálculo de adiposidade subcutânea, enquanto que a área em verde foi usada para cálculo de adiposidade visceral. Imagens cedida pelo serviço de Radiologia do HC-FMRP-USP.

Para análise da gordura hepática foi selecionada a região central com melhor posicionamento do fígado, sendo delimitadas quatro regiões de interesse (ROI) no tamanho $10 \mathrm{~mm}^{2}$, nos segmentos VI/VII, V/VIII, IV e II/III. Os quatro ROIs foram posicionados evitando grandes vasos intrahepáticos. (figura 4 ). O cálculo da fração de gordura hepática utilizando-se a média das 4 medidas seguiu a fórmula descrita por Fishbein e colaboradores (FISHBEIN et al, 2005) $=\left(\mathrm{IS}_{\mathrm{em} \text {-fase }}-\mathrm{IS}_{\text {fora-defase }}\right) /$ $2 \mathrm{IS}_{\text {em-fase, }}$ onde valores acima de $9 \%$ foram considerados como infiltração gordurosa hepática. 


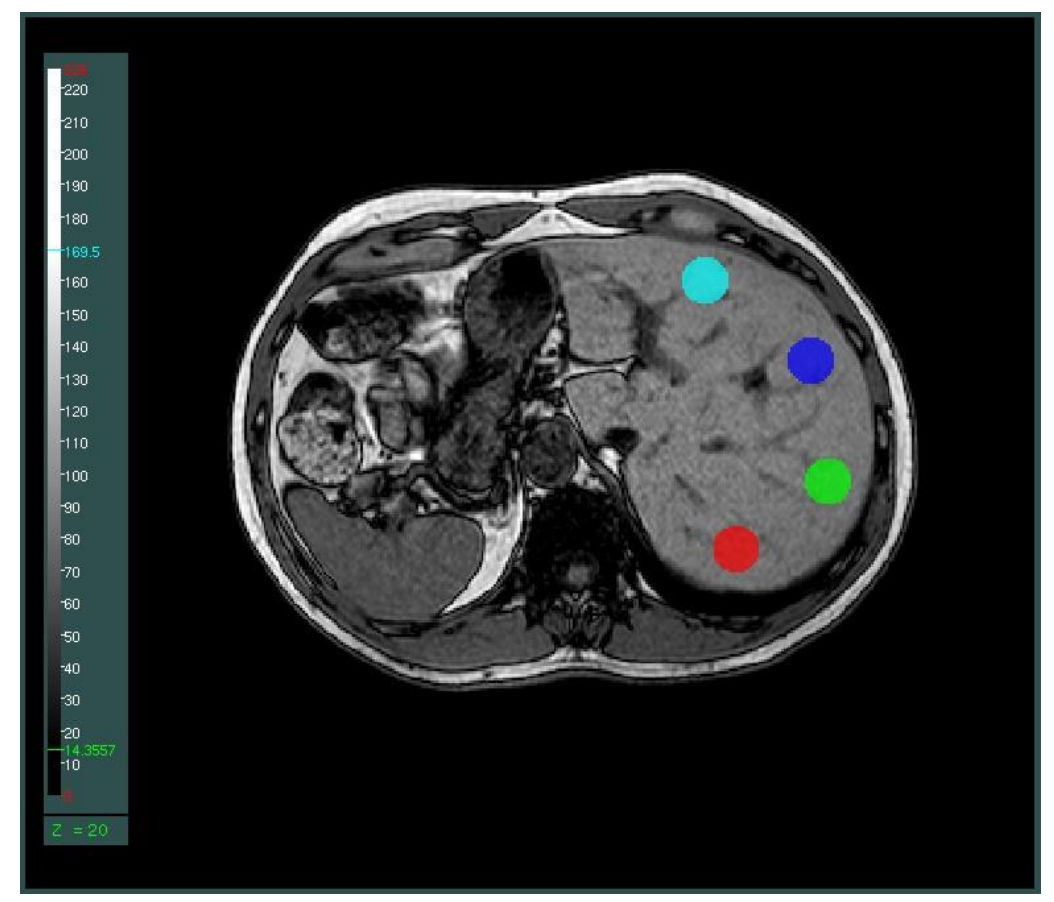

Figura 4: Regiões de interesse selecionadas em imagem de RM de abdome para cálculo de gordura hepática. Imagem cedida pelo serviço de Radiologia do HC-FMRP-USP.

\subsubsection{Radiografia}

Todos os indivíduos deste estudo realizaram radiografia simples de mão e punho esquerdo para avaliação da idade óssea pelo método de Greulich Pyle. As leituras das idades ósseas foram realizadas por três examinadores independentes. Quando houve discordância entre os laudos, foi assumido o valor com duas concordâncias.

\subsection{Análise estatística}

Os dados foram armazenados em planilha do Excel e os valores foram expressos em mediana, médias e desvio padrão. GC e GO foram comparados por meio do teste Mann-Whitney quanto às variáveis idade, IMC, glicemia de jejum, cálcio total ,fosfatase alcalina,fósforo inorgânico, CTX, colesterol total e frações, triglicerídeos, IGF-I, IGFBP3, expressão do gene do IGF1R, DMO, AMO e composição corporal. Os valores de IGF-I e IGFBP-3 foram ajustados para sexo e idade antes da análise (IGF-Ic e IGFBP-3c, respectivamente). 
Para correlacionar as variáveis acima, foi utilizado o modelo de correlação de Spearman e os valores expressos em coeficiente de correlação (r). Significância estatística foi assumida para $p<0,05$. O software utilizado foi o Graphpad Prism

5.0 .

Outro método de avaliação estatística foi utilizado para associar DMO em L3 com as variáveis AMO, expressão o gene do IGF1R, IGF-I e IMC. Foram ajustados modelos de regressão linear simples, através do proc GLM do software SAS 9.4. Foram obtidas estimativas e seus intervalos de confiança $95 \%$, bem como o coeficiente de determinação (R2), que indica a variabilidade das variáveis dependente que pode ser explicada pela variável independente. 


\section{RESULTADOS}

As características clínicas (sexo, idade, altura e IMC) dos indivíduos do GC e GO estão apresentadas na Tabela 1. Não houve diferença significativa entre os sexos, idades e alturas dos indivíduos. Como esperado, houve diferença entre os grupos quanto IMC, com média maior nos indivíduos do grupo obeso $(\mathrm{p}<0,05)$.

Tabela 1: Idade e IMC. Valores expressos em média \pm DP e mediana (entre parênteses).

\begin{tabular}{cccc} 
& $\begin{array}{c}\text { GC } \\
(\mathbf{n}=\mathbf{1 5})\end{array}$ & $\begin{array}{c}\text { GO } \\
(\mathbf{n = 1 5})\end{array}$ & $\mathbf{p}$ valor \\
\hline Idade (anos) & $13,9 \pm 1,85(13,92)$ & $12,78 \pm 1,97(12,25)$ & 0,088 \\
\hline Peso (kg) & $49,04 \pm 8,2(50,0)$ & $81,69 \pm 21,2(77,9)$ & $<0,05$ \\
\hline Altura (m) & $1,61 \pm 0,08(1,60)$ & $1,59 \pm 0,11(1,60)$ & 0,78 \\
\hline IMC $\left(\mathbf{k g} / \mathbf{m}^{2}\right)$ & $18,59 \pm 2,2(17,70)$ & $31,45 \pm 6,1(31,50)$ & $<0,05$ \\
\hline
\end{tabular}

Nota: teste Mann Whitney. GC: grupo controle, GO: grupo obeso, IMC: índice de massa corporal, DP:desvio padrão, n: número de pacientes, F: feminino, M: masculino.

Os resultados referentes às dosagens bioquímicas dos dois grupos estão descritos na Tabela 2. O GO apresentou valores séricos de TGP, LDL colesterol e triglicerídeos significativamente maiores que o GC, enquanto o GC apresentou maiores níveis séricos de HDL colesterol em mg/dL, (p <0,05). Os valores séricos de glicemia de jejum, uréia, creatinina e TGO não foram diferentes entre os grupos. 
Tabela 2: Dados de marcadores bioquímicos e lipidograma. Valores expressos em média \pm DP e mediana (entre parênteses). GC

$\mathrm{GO}$

$\mathrm{p}$ valor

$(\mathrm{n}=15)$

$(\mathrm{n}=15)$

\begin{tabular}{|l|l|c|c|}
\hline Glicemia (mg/dL) & $81,93 \pm 4,6(82,0)$ & $78,67 \pm 6,3(79,0)$ & 0,10 \\
\hline TGO (U/L) & $19,22 \pm 3,7(19,6)$ & $20,9 \pm 6,4(21,0)$ & 0,50 \\
\hline TGP (U/L) & $14,5 \pm 4,1(14,8)$ & $21,6 \pm 10,6(18,0)$ & $<0,05$ \\
\hline Uréia (mg/dL) & $22,0 \pm 4,4(24,0)$ & $22,8 \pm 6,1(24,0)$ & 0,64 \\
\hline Creatinina (mg/dL) & & & 0,36 \\
\hline Colesterol total (mg/dL) & $0,71 \pm 0,1(0,67)$ & $0,67 \pm 0,1(0,66)$ & 0,09 \\
\hline HDL colesterol (mg/dL) & $147,6 \pm 18,8(151,0)$ & $177,9 \pm 51,7(184,0)$ & \\
\hline Triglicerídeos (mg/dL) & & & $<0,05$ \\
\hline colesterol & $44,8 \pm 11,4(46,4)$ & $36,6 \pm 7,4(36,4)$ & $<0,05$ \\
\hline (mg/dL) & $86,8 \pm 14,0(89,0)$ & $114,1 \pm 44,3(122,0)$ & $<0,05$ \\
\hline
\end{tabular}

Nota: teste Mann Whitney. GC: grupo controle, GO: grupo obeso. TGO: transaminase glutâmico-oxalacética. TGP: Transaminase glutâmico-pirúvica. DP: desvio padrão. n: número de pacientes.

A tabela 3 descreve os resultados encontrados na avaliação do metabolismo ósseo e na dosagem sérica de CTx. O GO apresentou valores maiores em relação a cálcio total corrigido para albumina em $\mathrm{mg} / \mathrm{dL}$ e fosfatase alcalina em $\mathrm{U} / \mathrm{L}$, porém sem diferença estatística $(\mathrm{p}>0,05)$. O fósforo inorgânico em mg/dL, e CTx em ng/mL foram maiores no GC, também sem diferença estatística ( $p>0,05)$. Apesar das diferenças de valores entre o GC e GO, todos os indivíduos apresentaram valores dentro dos limites da normalidade segundo os valores de referências. 
Tabela 3: Dados do metabolismo do cálcio e CTX. Valores expressos em média \pm DP e mediana (entre parênteses).

\begin{tabular}{|c|c|c|c|}
\hline & $\begin{array}{c}\text { GC } \\
(n=15)\end{array}$ & $\begin{array}{c}\text { GO } \\
(n=15)\end{array}$ & p valor \\
\hline $\begin{array}{l}\text { Cálcio total c } \\
\text { (mg/dL) }\end{array}$ & $9,6 \pm 0,2(9,6)$ & $9,8 \pm 0,4(9,7)$ & 0,11 \\
\hline $\begin{array}{c}\text { Fósforo inorgânico } \\
\text { (mg/dL) }\end{array}$ & $4,5 \pm 0,4(4,5)$ & $4,4 \pm 0,4(4,5)$ & 0,62 \\
\hline $\begin{array}{c}\text { Fosfatase alcalina } \\
(\mathrm{U} / \mathrm{L})\end{array}$ & $398,7 \pm 215,6(247)$ & $438,5 \pm 190,3(471)$ & 0,74 \\
\hline $\begin{array}{c}\text { CTx } \\
(\mathbf{n g} / \mathbf{m L})\end{array}$ & $1,3 \pm 0,6(1,0)$ & $1,14 \pm 0,52(1,0)$ & 0,30 \\
\hline
\end{tabular}

Nota: teste Mann Whitney. GC: grupo controle, GO: grupo obeso. Cálcio total c: Cálcio total corrigido para valores séricos de albumina. CTx: telopeptídeo carboxiterminal do colágeno tipo I. DP: desvio padrão. n: número de pacientes.

A tabela 4 mostra resultados da composição corporal de todos os indivíduos em estudo,

mediante a densitometria óssea. Como esperado, o GO apresentou valores significativamente maiores que o GC em todos os parâmetros medidos, com p <0,05.

Tabela 4: Composição corporal mediante densitometria óssea. Valores expressos em média \pm DP e mediana (entre parênteses).

\begin{tabular}{|c|c|c|c|}
\hline & $\begin{array}{c}\text { GC } \\
(n=15)\end{array}$ & $\begin{array}{c}\text { GO } \\
(n=15)\end{array}$ & p valor \\
\hline $\begin{array}{c}\text { Gordura Corporal Total } \\
\text { (g) }\end{array}$ & $13782 \pm 4293(12333)$ & $34701 \pm 13322(30273)$ & $<0,05$ \\
\hline $\begin{array}{c}\text { Massa Magra sem Osso } \\
(\mathrm{g})\end{array}$ & $32254 \pm 6982(30406)$ & $43379 \pm 11771(40472)$ & $<0,05$ \\
\hline $\begin{array}{l}\text { Porcentagem de Gordura } \\
\text { Corporal Total }(\%)\end{array}$ & $28,9 \pm 7,3(30,6)$ & $42,9 \pm 7,1(44,6)$ & $<0,05$ \\
\hline $\begin{array}{c}\text { Porcentagem de massa magra } \\
(\%)\end{array}$ & $65,69 \pm 7,0964,4)$ & $53,35 \pm 6,7(52,0)$ & $<0,05$ \\
\hline $\begin{array}{c}\text { Massa Gorda em Tronco } \\
\text { (g) }\end{array}$ & $5042 \pm 1799(4351)$ & $16354 \pm 6704(12223)$ & $<0,05$ \\
\hline $\begin{array}{c}\text { Massa Magra em Tronco } \\
\text { (g) }\end{array}$ & $14969 \pm 3061(14489)$ & $21050 \pm 6412(20082)$ & $<0,05$ \\
\hline $\begin{array}{c}\text { Gordura em Tronco } \\
(\%)\end{array}$ & $24,5 \pm 6,5(25,1)$ & $42,4 \pm 8,6(42,8)$ & $<0,05$ \\
\hline
\end{tabular}

Nota: teste Mann Whitney. GC: grupo controle, GO: grupo obeso. DP: desvio padrão. n: número de pacientes. 
A DMO, por meio da densitometria óssea, não mostrou diferença estatística entre as DMO em coluna lombar (L1-L4), L3 e CT quando representadas em g/cm² ou areal. Porém, revelou valores maiores em indivíduos do GO, com significância estatística em coluna lombar (L1-L4) e L3 quando referentes ao $\mathrm{Z}$ score, $(\mathrm{Z}$ score $) \mathrm{c}$ e $\mathrm{DMO}$ em $\mathrm{g} \mathrm{cm}^{3}$ ou volumétrica . Também houve maior valor da DMO -CT no GO quando referente ao Z score, como mostra a tabela 5.

Tabela 5: Dados da densitometria óssea referentes a DMO. Valores expressos em média \pm DP e mediana (entre parênteses)

\begin{tabular}{|c|c|c|c|}
\hline & $\begin{array}{c}\text { GC } \\
(n=15)\end{array}$ & $\begin{array}{c}\text { GO } \\
(n=15)\end{array}$ & $\mathrm{p}$ valor \\
\hline DMO - L1- L4 (g/cm²)a & $0,78 \pm 0,1(0,77)$ & $0,90 \pm 0,1(0,85)$ & 0,08 \\
\hline DMO - L1 - L4 (Z score) & $-0,57 \pm 1,1(-0,2)$ & $1,22 \pm 0,7(1,3)$ & $<0,05$ \\
\hline DMO - L1 - L4 (Z score) c & $-0,94 \pm 0,9(-0,9)$ & $0,18 \pm 0,9(-0,2)$ & $<0,05$ \\
\hline DMO - L1 - L4 $\left(\mathrm{g} / \mathrm{cm}^{3}\right) \mathrm{v}$ & $0,10 \pm 0,01(0,1)$ & $0,12 \pm 0,02(0,1)$ & $<0,05$ \\
\hline DMO-L3 $\left(\mathrm{g} / \mathrm{cm}^{2}\right) \mathbf{a}$ & $0,79 \pm 0,1(0,78)$ & $0,92 \pm 0,19(0,84)$ & 0,05 \\
\hline DMO - L3 (Z score) & $-0,55 \pm 0,84(-0,45)$ & $1,24 \pm 0,77(1,1)$ & $<0,05$ \\
\hline DMO - L3 (Z score) c & $-1,0 \pm 0,9(-1,0)$ & $0,09 \pm 1,0(-0,4)$ & $<0,05$ \\
\hline DMO - L3 $\left(\mathrm{g} / \mathrm{cm}^{3}\right) \mathrm{v}$ & $0,21 \pm 0,02(0,21)$ & $0,25 \pm 0,05(0,23)$ & $<0,05$ \\
\hline DMO - CT $\left(\mathrm{g} / \mathrm{cm}^{2}\right) \mathrm{a}$ & $1,0 \pm 0,07(1,0)$ & $1,1 \pm 0,12(1,0)$ & 0,67 \\
\hline DMO - CTsc $\left(\mathrm{g} / \mathrm{cm}^{2}\right) \mathbf{a}$ & $2,0 \pm 0,64(2,26)$ & $1,5 \pm 0,67(1,32)$ & 0,10 \\
\hline DMO - CT (Z score) & $1,38 \pm 1,47(1,3)$ & $2,4 \pm 0,78(2,5)$ & $<0,05$ \\
\hline DMO - CT (Z score) c & $0,96 \pm 1,29(0,6)$ & $1,14 \pm 1,14(1,10)$ & 0,30 \\
\hline DMO -CT $\left(\mathrm{g} / \mathrm{cm}^{3}\right) \mathrm{v}$ & $0,02 \pm 0,001(0,02)$ & $0,02 \pm 0,001(0,02)$ & 0,13 \\
\hline DMO -CTsc $\left(\mathrm{g} / \mathrm{cm}^{3}\right) \mathrm{v}$ & $0,12 \pm 0,04(2,26)$ & $1,5 \pm 0,67(1,32)$ & 0,19 \\
\hline
\end{tabular}

Nota: teste Mann Whitney. GC: grupo controle, GO: grupo obeso. DMO: Densidade mineral óssea, CTsc: Corpo total sem cabeça.

A figura 5 mostram que o GO apresentou maior DMO em Z score da coluna lombar (L1-L4) e L3. No entanto, quando ajustada a DMO para idade óssea, a diferença diminui, apesar de ainda manter $\mathrm{p}<0,05$. 

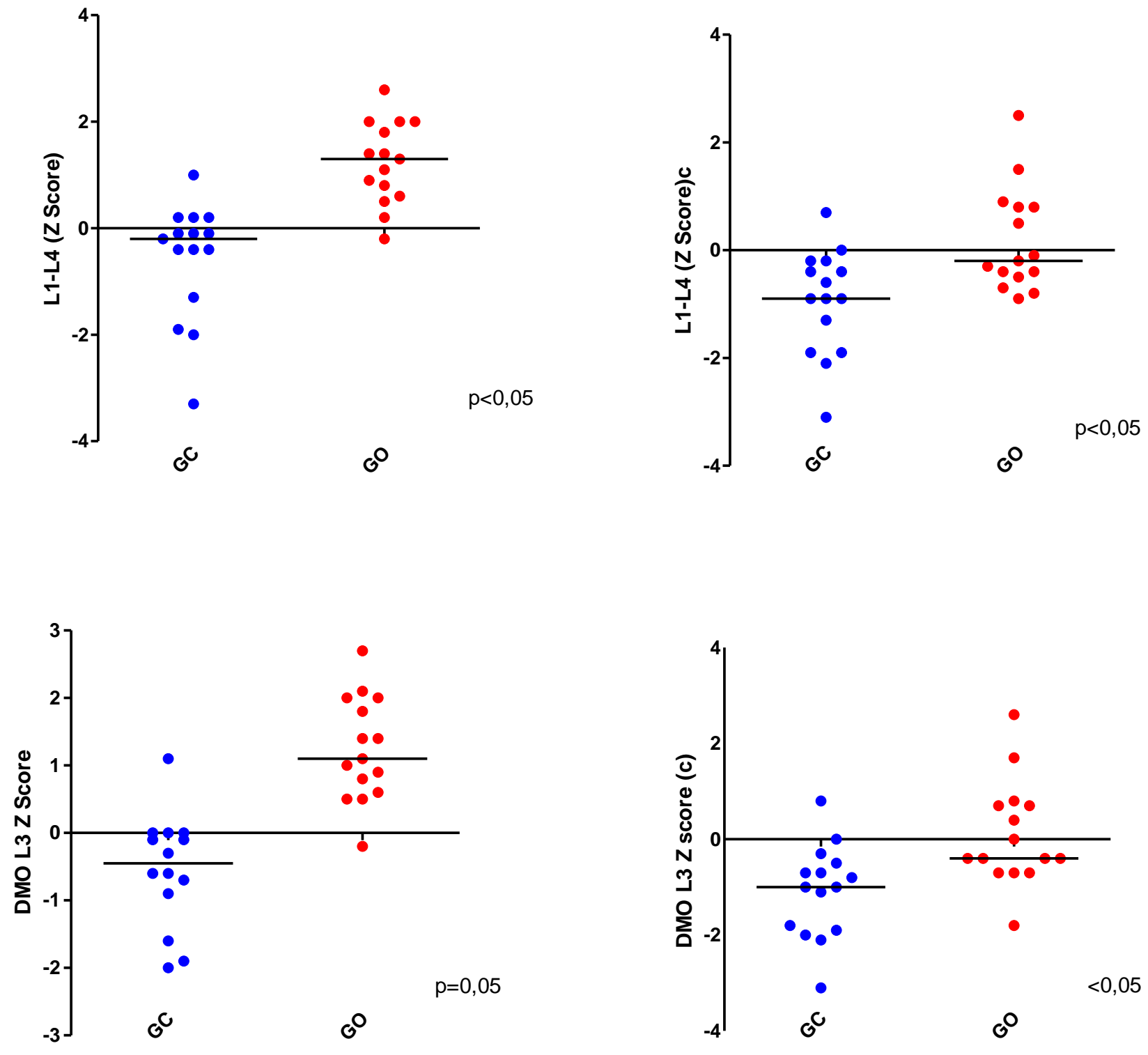

Figure 5: DMO de coluna lombar (L1-L4) e L3 nos dois grupos por Z score $(p<0,05)$ e por Z score $(c)(p<0,05)$. Linha contínua representa mediana. $\mathrm{GC}=\mathrm{Grupo}$ controle/GO =Grupo obeso.

A DMO em coluna lombar (L1-L4) não apresentou diferença estatística quando representada em $\mathrm{g} / \mathrm{cm}^{2}$ ou areal. Porém, quando o ajuste dos valores é feito para $\mathrm{g} / \mathrm{cm}^{3}$ ou volumétrico o GO mostrou maior DMO. (figura 6) . 

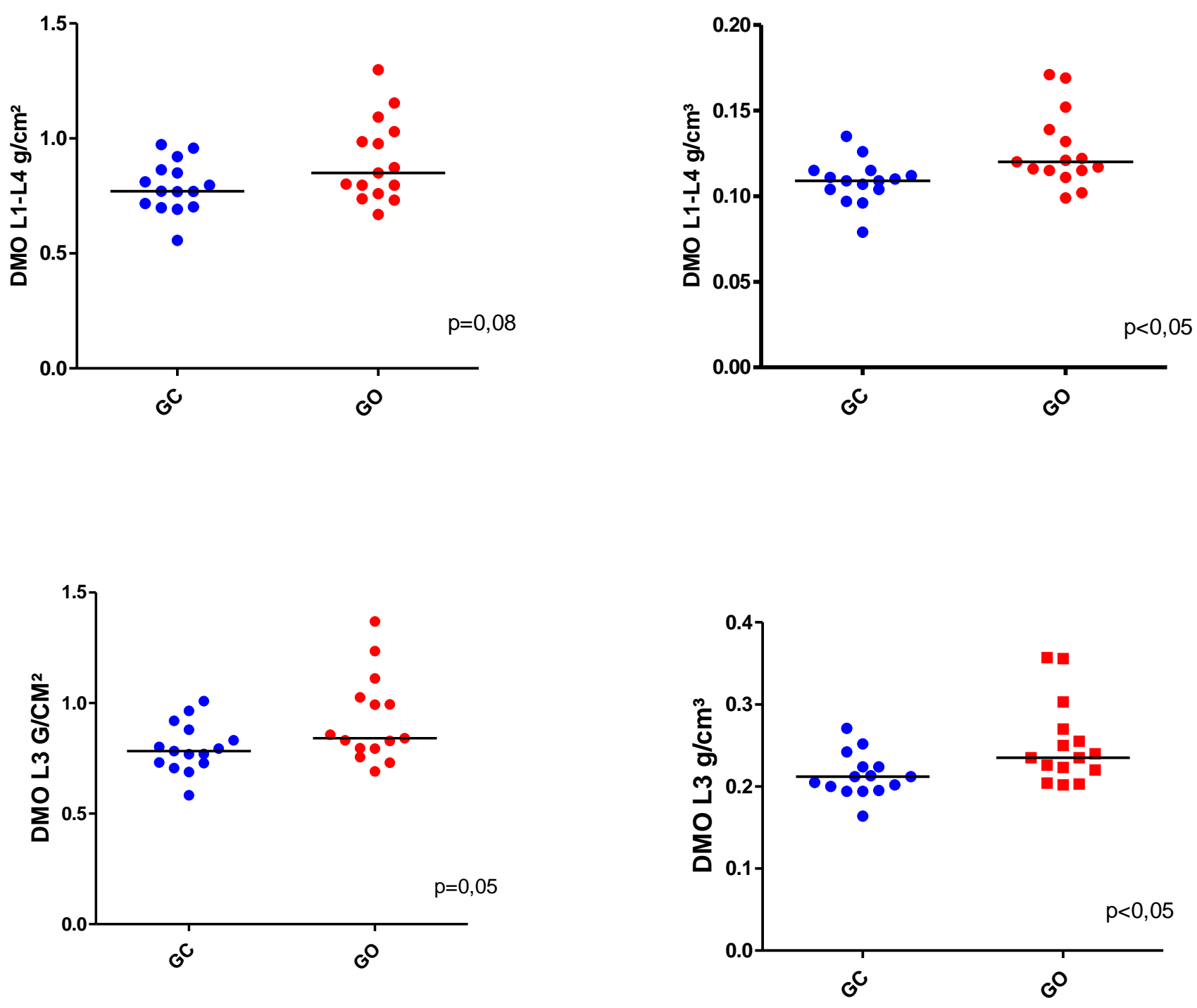

Figure 6: DMO de coluna lombar (L1-L4) e L3 nos dois grupos por g/ $\mathrm{cm}^{2}$ e por $\mathrm{g} / \mathrm{cm}^{3}$. Linha contínua representa mediana. $\mathrm{GC}=$ Grupo controle/GO =Grupo obeso.

A tabela 6 revela dados da ressonância magnética de coluna lombar e abdome. Como previsto, o GO apresentou valores significativamente maiores da área subcutânea em $\mathrm{mm}^{2}$, área visceral em $\mathrm{mm}^{2}$ e porcentagem de gordura hepática. No entanto, os dois grupos não apresentaram diferença estatísica na $\operatorname{AMO}(\mathrm{p}=0,45)$. 
Tabela 6: Dados da ressonância magnética de coluna lombar e abdome referentes a AMO, área subcutânea, área visceral e gordura hepática.Valores expressos em média \pm DP e mediana (entre parênteses).

$$
\text { GC }
$$

GO

P valor

$$
\text { (n=15) }
$$

$(\mathbf{n}=\mathbf{1 5})$

\begin{tabular}{|c|c|c|c|}
\hline $\begin{array}{c}\text { AMO } \\
(\%)\end{array}$ & $31,4 \pm 8,1(30,1)$ & $29,4 \pm 8,5(24,2)$ & 0,53 \\
\hline $\begin{array}{c}\text { Àrea subcutânea } \\
\left(\mathbf{m m}^{\mathbf{2}}\right)\end{array}$ & $10740 \pm 6404(9704)$ & $34890 \pm 14050(32190)$ & $<0,05$ \\
\hline $\begin{array}{c}\text { Área visceral } \\
\left(\mathbf{m m}^{2}\right)\end{array}$ & $1205 \pm 925,6(1012)$ & $4161 \pm 3150(3987)$ & $<0,05$ \\
\hline $\begin{array}{c}\text { Gordura hepática } \\
(\%)\end{array}$ & $1,1 \pm 0,5(0,93)$ & $10,2 \pm 12,2(2,9)$ & $<0,05$ \\
\hline
\end{tabular}

Nota: teste Mann Whitney. GC: grupo controle, GO: grupo obeso. AMO: Adiposidade da medula óssea

A figura 7 revela que não houve diferença significativa entre os dois grupos quanto à porcentagem de AMO.

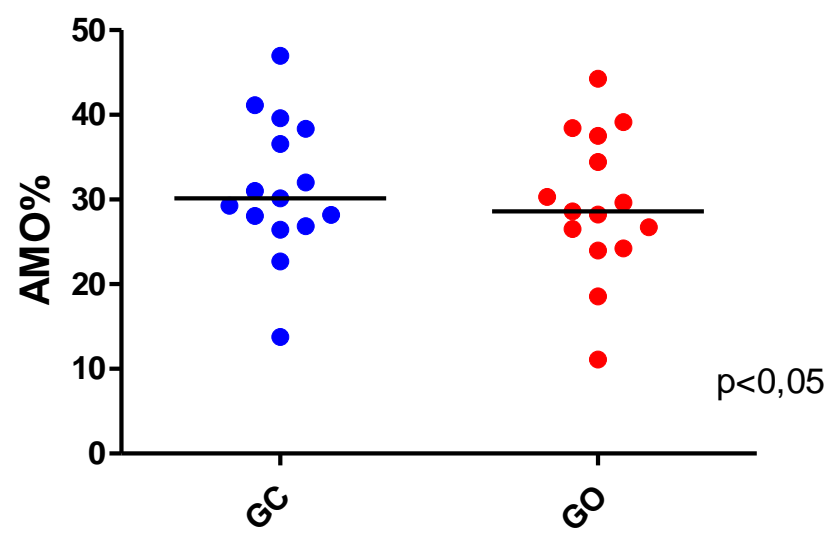

Figura 7: Porcentagem de AMO entre os dois grupos. Linha contínua representa mediana. GC=Grupo controle/GO =Grupo obeso.

Em relação ao sistema IGF, os grupos não apresentaram diferença estatística quanto aos valores séricos de IGF-I, IGFBP3 corrigidos para idade e sexo, assim como nos valores da expressão do RNA do gene do IGF1R, realizada por PCR em tempo real. (Tabela 7) 
Tabela 7: Dados referentes ao sistema IGF: IGF-I, IGFBP3 e expressão do gene do IGF1R. Valores expressos em média \pm DP e mediana (entre parênteses)

\begin{tabular}{|c|c|c|c|}
\hline & $\begin{array}{c}\text { GC } \\
(n=15)\end{array}$ & $\begin{array}{c}\text { GO } \\
(n=15)\end{array}$ & $P$ valor \\
\hline IGF-I c & $0,53 \pm 0,6(0,25)$ & $0,32 \pm 0,6(0,18)$ & 0,45 \\
\hline IGFBP3c & $-0,07 \pm 0,14(-0,07)$ & $-0,02 \pm 0,26(-0,08)$ & 0,86 \\
\hline IGF1R -2АACT & $0,94 \pm 0,04(0,94)$ & $0,94 \pm 0,03(0,95)$ & 0,98 \\
\hline
\end{tabular}

Nota: teste Mann Whitney. GC: grupo controle, GO: grupo obeso. IGF-I c: IGF-I corrigido para idade e sexo. IGFBP3c: IGFBP3 corrigido para idade e sexo. DP: desvio padrão. n: número de pacientes.

A figura 8 mostra que não houve diferença significativa entre os valores da expressão do RNA do gene do IGF1R entre o GC e GO.

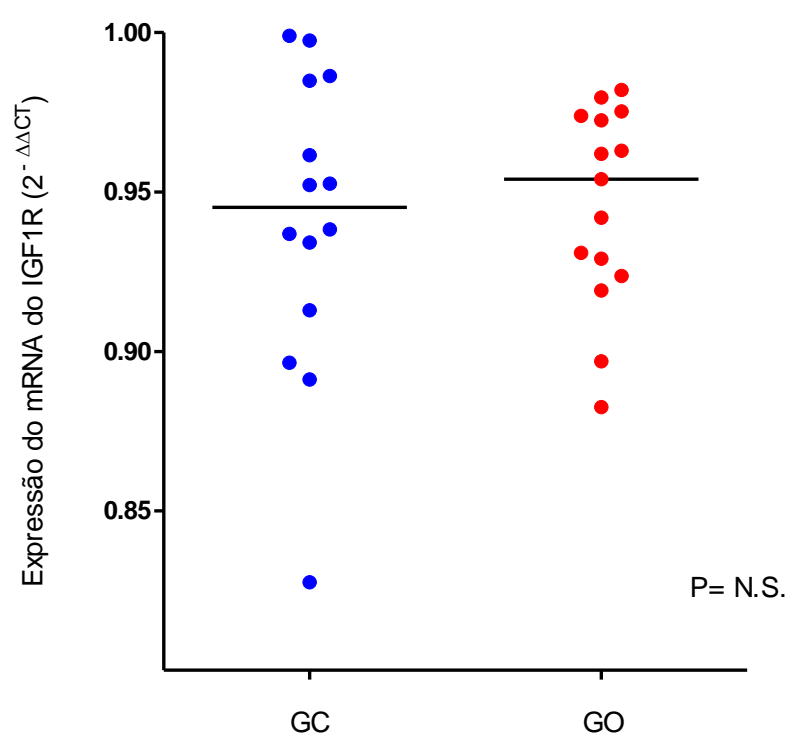

Figure 8: Expressão do RNA do gene do IGF1R $\left(2^{-\Delta \Delta C T}\right)$ nos dois grupos. Linha contínua representa mediana. GC=Grupo controle/GO =Grupo obeso.

A figura 9 mostra que também não houve diferença entre os grupos quanto a valores de IGF-Ic e IGFBP-3c. 

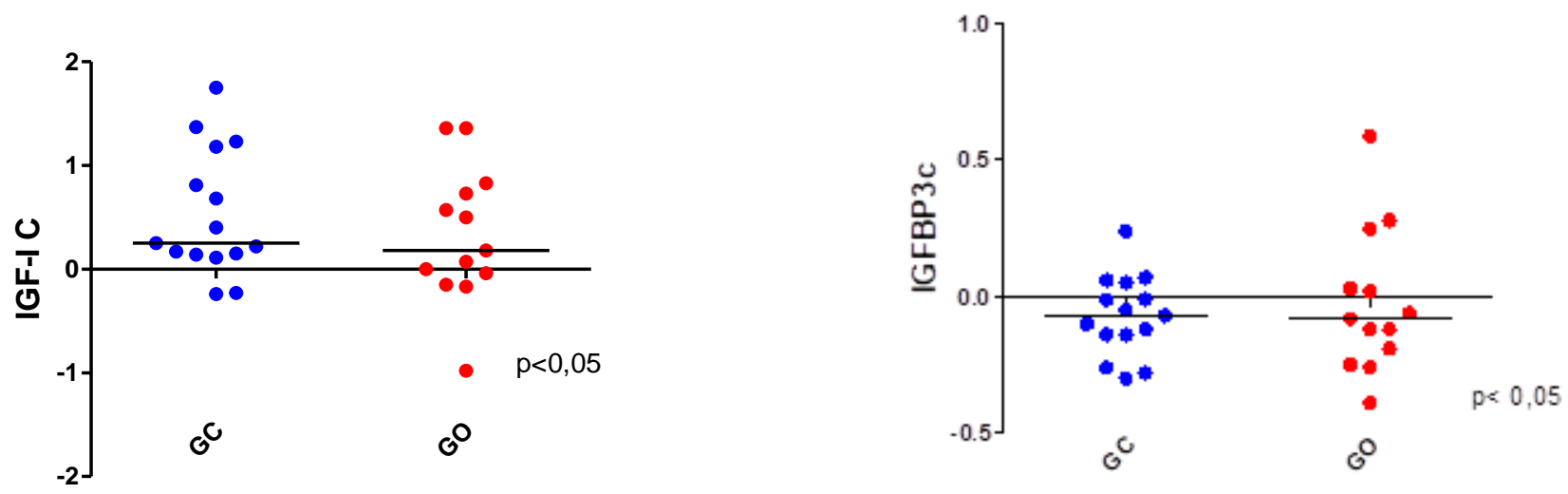

Figure 9: Valores de IGF-Ic e IGFBP-3c nos dois grupos. Linha contínua representa mediana. GC=Grupo controle/GO =Grupo obeso.

Foram realizadas correlações entre as variáveis relativas à massa óssea e AMO para o GC e o GO separadamente (tabelas 8 e 9). Tanto o GC quanto GO não apresentaram correlações entre AMO e os parâmetros da DMO.

Tabela 8: Correlação entre variáveis relativas à massa óssea e adiposidade da medula óssea nos indivíduos do grupo controle. Valores expressos coeficiente de correlação (r).

\begin{tabular}{|c|c|c|c|c|} 
& $\begin{array}{c}\text { DMO L3 } \\
\left(\mathbf{g} / \mathbf{c m}^{2}\right) \mathbf{a}\end{array}$ & $\begin{array}{c}\text { DMO L3 } \\
(\mathbf{Z} \text { score })\end{array}$ & $\begin{array}{c}\text { DMO L3 } \\
(\mathbf{Z s c o r e}) \mathbf{c}\end{array}$ & $\begin{array}{c}\text { DMO L3 } \\
\left(\mathbf{g} / \mathbf{c m}^{\mathbf{3}}\right) \mathbf{v}\end{array}$ \\
\hline AMO $(\%)$ & 0,28 & 0,32 & $-0,01$ & 0,11 \\
\hline
\end{tabular}

Nota: Correlação de Spearman. DMO: Densidade mineral óssea, CT: Corpo total , AMO: Adiposidade da medula óssea, a: areal ,c: corrigida para idade óssea, v: volumétrica, sc: sem cabeça* $\mathrm{P}<0,05$.

Tabela 9: Correlação entre variáveis relativas à massa óssea e adiposidade da medula óssea nos indivíduos do grupo obeso. Valores expressos em coeficiente de correlação (r).

\begin{tabular}{|c|c|c|c|c|} 
& $\begin{array}{c}\text { DMO L3 } \\
\left(\mathbf{g} / \mathbf{c m}^{2}\right) \mathbf{a}\end{array}$ & $\begin{array}{c}\text { DMO L3 } \\
(\mathbf{Z} \text { score })\end{array}$ & $\begin{array}{c}\text { DMO L3 } \\
(\mathbf{Z s c o r e}) \mathbf{c}\end{array}$ & $\begin{array}{c}\text { DMO L3 } \\
\left(\mathbf{g} / \mathbf{c m}^{3}\right) \mathbf{v}\end{array}$ \\
\hline AMO(\%) & $-0,15$ & $-0,2$ & 0,01 & $-0,07$ \\
\hline
\end{tabular}

Nota: Correlação de Spearman. DMO: Densidade mineral óssea, CT: Corpo total , AMO: Adiposidade da medula óssea, a: areal ,c: corrigida para idade óssea, v: volumétrica, sc: sem cabeça $* \mathrm{P}<0,05$. 
A tabela 10 mostra que o GC apresentou correlação negativa entre IGF-Ic e DMO em CTsc tanto em $\mathrm{g} / \mathrm{cm}^{2}$ quanto em $\mathrm{g} / \mathrm{cm}^{3}$. IGFBP3c e Expressão do IGF1R não obtiveram correlação com DMO nesse grupo.

Tabela 10: Correlação entre variáveis relativas à massa óssea, adiposidade da medula óssea, valores séricos de IGF-I, IGFBP3 e expressão do RNA do IGF1R nos indivíduos do grupo controle. Valores expressos coeficiente de correlação (r).

\begin{tabular}{|c|c|c|c|c|c|c|c|}
\hline & $\begin{array}{c}\text { DMO } \\
\text { L1-L4 } \\
\left(\mathrm{g} / \mathrm{cm}^{2}\right) \mathbf{a}\end{array}$ & $\begin{array}{l}\text { DMO } \\
\text { L1-L4 } \\
\text { (Z score) }\end{array}$ & $\begin{array}{c}\text { DMO } \\
\text { L1- L4 } \\
\text { (Z score) }\end{array}$ & $\begin{array}{c}\text { DMO } \\
\text { L1-L4 } \\
\left(\mathrm{g} / \mathrm{cm}^{3}\right) \mathbf{v}\end{array}$ & $\begin{array}{c}\text { DMO CTsc } \\
\left(\mathrm{g} / \mathrm{cm}^{2}\right) \mathbf{a} \\
\end{array}$ & $\begin{array}{l}\text { DMO CTsc } \\
\underline{\left(\mathrm{g} / \mathbf{c m}^{3}\right) \mathbf{v}}\end{array}$ & $\begin{array}{l}\text { AMO } \\
(\%)\end{array}$ \\
\hline IGF-I c & $-0,37$ & $-0,06$ & $-0,007$ & $-0,37$ & $-0,60 *$ & $-0,63^{*}$ & $-0,41$ \\
\hline IGFBP3c & $-0,22$ & $-0,13$ & 0,06 & $-0,09$ & $-0,45$ & 0,29 & $-0,20$ \\
\hline $\begin{array}{l}\text { IGF1R - } \\
2 \Delta \Delta C T\end{array}$ & 0,037 & 0,14 & 0,43 & 0,18 & $-0,33$ & $-0,37$ & 0,002 \\
\hline
\end{tabular}

Nota: Correlação de Spearman. DMO: Densidade mineral óssea, CTsc: Corpo total sem cabeça AMO: Adiposidade da medula óssea, IGF-I c: IGF-I corrigido para idade e sexo. IGFBP3c:IGFBP3 corrigido para idade e sexo.* P<0,05. \# $0,05<\mathrm{P}<0,07$.

A tabela 11 mostra que o GO apresentou correlação positiva entre IGFBP3 em CTsc em $\mathrm{g} / \mathrm{cm}^{2}$.Porém ao corrigir os valores para volumétrico essa correlação desaparece. IGF-Ic e Expressão do IGF1R não obtiveram correlação com DMO nesse grupo

Tabela 11: Correlação entre variáveis relativas à massa óssea, adiposidade da medula óssea, valores séricos de IGF-I, IGFBP3 e expressão do RNA do IGF1R nos indivíduos do grupo obeso. Valores expressos coeficiente de correlação (r).

\begin{tabular}{|c|c|c|c|c|c|c|c|}
\hline & $\begin{array}{c}\text { DMO } \\
\text { L1-L4 } \\
\left(\mathrm{g} / \mathrm{cm}^{2}\right) \mathbf{a}\end{array}$ & $\begin{array}{c}\text { DMO } \\
\text { L1-L4 } \\
\text { Zscore }\end{array}$ & $\begin{array}{c}\text { DMO } \\
\text { L1 - L4 } \\
(\mathrm{Z} \text { score }) \text { c }\end{array}$ & $\begin{array}{c}\text { DMO } \\
\text { L1-L4 } \\
\left(\mathrm{g} / \mathrm{cm}^{3}\right) \mathbf{v}\end{array}$ & $\begin{array}{l}\text { DMO CTsc } \\
\left(\underline{\left(\mathrm{g} / \mathrm{cm}^{2}\right) \mathbf{a}}\right.\end{array}$ & $\begin{array}{l}\text { DMO CTsc } \\
\underline{\left(\mathrm{g} / \mathrm{cm}^{3}\right) \mathbf{v}}\end{array}$ & $\begin{array}{l}\text { AMO } \\
(\%)\end{array}$ \\
\hline IGF-I c & $-0,06$ & 0,03 & $-0,05$ & 0,02 & $-0,21$ & 0,25 & 0,20 \\
\hline IGFBP3c & $-0,31$ & 0,04 & 0,55 & $-0,32$ & $0,67 *$ & 0,46 & $-0,20$ \\
\hline $\begin{array}{l}\text { IGF1R - } \\
2 \Delta \Delta C T\end{array}$ & 0,37 & 0,13 & $-0,012$ & 0,41 & 0,10 & $-0,18$ & $-0,32$ \\
\hline
\end{tabular}

Nota: Correlação de Spearman. DMO: Densidade mineral óssea, CTsc: Corpo total sem cabeça AMO: Adiposidade da medula óssea, IGF-I c: IGF-I corrigido para idade e sexo. IGFBP3c:IGFBP3 corrigido para idade e sexo.* $\mathrm{P}<0,05$. \# $0,05<\mathrm{P}<0,07$

Os indivíduos do GC não apresentaram correlação do cálcio total corrigido para valores séricos de albumina com DMO da coluna lombar (L1-L4), ou do CTsc. No entanto, observou-se correlação negativa da fosfatase alcalina sérica em U/L com a DMO areal e volumétrica em CL(L1-L4). 
Os valores de CTx séricos tiveram correlação negativa com a DMO areal e volumétrica em coluna lombar (L1-L4). Não houve correlação entre os valores séricos de cálcio total corrigido, fósforo inorgânico, fosfatase alcalina e CTx com porcentagem de AMO (tabela 12).

Tabela 12: Correlação entre variáveis relativas à massa óssea, adiposidade da medula óssea, valores séricos de cálcio total, fósforo inorgânico, fosfatase alcalina e CTX nos indivíduos do grupo controle. Valores expressos coeficiente de correlação (r).

\begin{tabular}{|c|c|c|c|c|c|c|c|}
\hline & $\begin{array}{r}\text { DMO } \\
\text { L1 - L4 } \\
\left(\mathrm{g} / \mathrm{cm}^{2}\right) \mathrm{a}\end{array}$ & $\begin{array}{c}\text { DMO } \\
\text { L1 - L4 } \\
\text { (Z score) }\end{array}$ & $\begin{array}{c}\text { DMO } \\
\text { L1 - L4 } \\
(\mathrm{Z} \text { score }) \text { c }\end{array}$ & $\begin{array}{c}\text { DMO } \\
\text { L1 - L4 } \\
\left(\mathrm{g} / \mathrm{cm}^{3}\right) \mathrm{v}\end{array}$ & $\begin{array}{l}\text { DMO - } \\
\text { CT sc } \\
\left(\mathrm{g} / \mathrm{cm}^{2}\right) \mathrm{a}\end{array}$ & $\begin{array}{l}\text { DMO - } \\
\text { CTsc } \\
\left(\mathrm{g} / \mathrm{cm}^{3}\right) \mathrm{v}\end{array}$ & $\begin{array}{c}\text { AMO } \\
(\%)\end{array}$ \\
\hline $\begin{array}{l}\text { Cálcio total c } \\
(\mathbf{m g} / \mathbf{d L})\end{array}$ & $-0,20$ & 0,20 & 0,35 & 0,09 & $-0,02$ & 0,03 & $-0,18$ \\
\hline $\begin{array}{c}\text { Fósforo } \\
\text { inorgânico } \\
(\mathbf{m g} / \mathbf{d L})\end{array}$ & $-0,40$ & 0,39 & 0,47 & $-0,33$ & $-0,20$ & $-0,14$ & 0,084 \\
\hline $\begin{array}{c}\text { Fosfatase } \\
\text { alcalina } \\
\text { (U/L) }\end{array}$ & $-0,59 *$ & 0,34 & 0,42 & $-0,59 *$ & $-0,06$ & 0,06 & 0,02 \\
\hline$\underset{(\mathbf{n g} / \mathbf{m L})}{\mathbf{C T x}}$ & $-0,74 *$ & 0,20 & 0,19 & $-0,71 *$ & $-0,24$ & $-0,04$ & $-0,19$ \\
\hline
\end{tabular}

Nota: Correlação de Spearman. DMO: Densidade mineral óssea, CT (SC): Corpo total sem cabeça AMO: Adiposidade da medula óssea, Cálcio total c: Cálcio total corrigido para valores séricos de albumina. CTx: telopeptídeo carboxiterminal do colágeno tipo $\mathrm{I}$ * $\mathrm{P}<0,05$.

O indivíduos do GO mostraram correlações semelhantes ao GC, não havendo correlação do cálcio total corrigido para valores séricos de albumina com DMO da coluna lombar (L1-L4) ou do CTsc. Já os valores séricos de fosfatase alcalina em U/L tiveram correlações negativas com DMO areal e volumétrica em coluna lombar (L1-L4) e CTsc areal, assim como os valores séricos de CTx. Não houve correlação entre os valores séricos de cálcio total corrigido, fósforo inorgânico, fosfatase alcalina e CTx com porcentagem de AMO (tabela 13). 
Tabela 13: Correlação entre variáveis relativas à massa óssea, adiposidade da medula óssea, valores séricos de cálcio total, fósforo inorgânico, fosfatase alcalina e CTX nos indivíduos do grupo obeso. Valores expressos coeficiente de correlação (r).

\begin{tabular}{|c|c|c|c|c|c|c|c|}
\hline & $\begin{array}{r}\text { DMO } \\
\text { L1 - L4 } \\
\left(\mathrm{g} / \mathrm{cm}^{2}\right) \mathrm{a}\end{array}$ & $\begin{array}{c}\text { DMO L1 - L4 } \\
\text { (Z score) }\end{array}$ & $\begin{array}{l}\text { DMO L1 - L4 } \\
\quad(\mathrm{Z} \text { score }) \text { c }\end{array}$ & $\begin{array}{c}\text { DMO } \\
\text { L1 - L4 } \\
\left(\mathrm{g} / \mathrm{cm}^{3}\right) \mathrm{v}\end{array}$ & $\begin{array}{l}\text { DMO - } \\
\text { CTsc } \\
\left(\mathrm{g} / \mathrm{cm}^{2}\right) \mathbf{a}\end{array}$ & $\begin{array}{c}\text { DMO - } \\
\text { CTsc } \\
\left(\mathrm{g} / \mathrm{cm}^{3}\right) \mathbf{v}\end{array}$ & $\begin{array}{c}\text { AMO } \\
(\%)\end{array}$ \\
\hline $\begin{array}{l}\text { Cálcio total c } \\
(\mathrm{mg} / \mathrm{dL})\end{array}$ & $-0,40$ & $-0,00$ & $-0,38$ & $-0,41$ & $-0,38$ & 0,06 & 0,03 \\
\hline $\begin{array}{c}\text { Fósforo inorgânico } \\
(\mathbf{m g} / \mathbf{d L})\end{array}$ & $-0,39$ & $-0,06$ & $-0,04$ & $-0,18$ & $-0,35$ & 0,04 & $-0,04$ \\
\hline $\begin{array}{c}\text { Fosfatase alcalina } \\
\text { (U/L) }\end{array}$ & $-0,70 *$ & $-0,08$ & $-0,13$ & $-0,61^{*}$ & $-0,70^{*}$ & $-0,24$ & 0,23 \\
\hline$\underset{(\mathbf{n g} / \mathrm{mL})}{\mathbf{C T x}}$ & $-0,65^{*}$ & $-0,10$ & $-0,29$ & $-0,53^{*}$ & $-0,71 *$ & $-0,54^{*}$ & 0,19 \\
\hline
\end{tabular}

Nota: Correlação de Spearman. DMO: Densidade mineral óssea, CT (SC): Corpo total sem cabeça AMO: Adiposidade da medula óssea, Cálcio total c: Cálcio total corrigido para valores séricos de albumina. CTx:telopeptídeo carboxiterminal do colágeno tipo I. * $\mathrm{P}<0,05$.

A tabela 14 revela que a massa gorda em tronco apresentou correlação positiva com a DMO areal em CL(L1-L4), assim como a gordura corporal total também apresentou correlação positiva com a DMO em CL(L1-L4), porém volumétrica. A DMO CTsc areal apresentou correlação positiva com a massa magra sem osso. Não houve correlação entre composição corporal com porcentagem de AMO (tabela 14).

Tabela 14: Correlação entre variáveis relativas à massa óssea, adiposidade da medula óssea e composição corporal nos indivíduos do grupo controle. Valores expressos coeficiente de correlação (r).

\begin{tabular}{|c|c|c|c|c|c|c|c|}
\hline & $\begin{array}{c}\text { DMO } \\
\text { L1 - L4 } \\
\left(\mathrm{g} / \mathrm{cm}^{2}\right) \mathrm{a}\end{array}$ & $\begin{array}{c}\text { DMO } \\
\text { L1 - L4 } \\
\text { (Z score }) \text { c }\end{array}$ & $\begin{array}{c}\text { DMO } \\
\text { L1 - L4 } \\
(\mathrm{Z} \text { score }) \text { c }\end{array}$ & $\begin{array}{c}\text { DMO } \\
\mathrm{L1}-\mathrm{L4} \\
\left(\mathrm{g} / \mathrm{cm}^{3}\right) \mathrm{v}\end{array}$ & $\begin{array}{c}\text { DMO - } \\
\text { CTsc } \\
\left(\mathrm{g} / \mathrm{cm}^{2}\right) \mathbf{a}\end{array}$ & $\begin{array}{c}\text { DMO - } \\
\text { CTsc } \\
\left(\mathrm{g} / \mathrm{cm}^{3}\right) \mathbf{v}\end{array}$ & $\begin{array}{r}\text { AMO } \\
(\%)\end{array}$ \\
\hline $\begin{array}{l}\text { Gordura } \\
\text { Corporal } \\
\text { Total (g) }\end{array}$ & 0,47 & 0,04 & 0,003 & $0,56 *$ & 0,078 & $-0,26$ & 0,24 \\
\hline $\begin{array}{l}\text { Massa Magra } \\
\text { sem Osso (g) }\end{array}$ & 0,43 & 0,13 & 0,13 & 0,084 & $0,64 *$ & $-0,04$ & $\begin{array}{c}- \\
0,10\end{array}$ \\
\hline $\begin{array}{l}\text { Massa Gorda em } \\
\text { Tronco (g) }\end{array}$ & $0,52 *$ & $-0,09$ & $-0,09$ & 0,014 & 0,15 & $-0,33$ & 0,31 \\
\hline
\end{tabular}

Nota: Correlação de Spearman. BMC: Conteúdo mineral ósseo, BMD: Densidade mineral óssea, CT (SC): Corpo total sem cabeça AMO: Adiposidade da medula óssea.* $\mathrm{P}<0,05$.

Os indivíduos do GO apresentaram correlações positivas da gordura corporal total , massa magra sem osso e massa gorda em troco com DMO em coluna lombar (L1-L4),e CTsc . Não houve correlação entre composição corporal e porcentagem de AMO neste grupo. 
Tabela 15: Correlação entre variáveis relativas à massa óssea, adiposidade da medula óssea e composição corporal nos indivíduos do grupo obeso. Valores expressos coeficiente de correlação (r).

\begin{tabular}{|c|c|c|c|c|c|c|c|}
\hline & $\begin{array}{l}\text { DMO } \\
\text { L1 - L4 } \\
\left(\mathrm{g} / \mathrm{cm}^{2}\right) \mathrm{a}\end{array}$ & $\begin{array}{l}\text { DMO } \\
\text { L1 - L4 } \\
\text { (Z score) }\end{array}$ & $\begin{array}{l}\text { DMO } \\
\text { L1 - L4 } \\
\text { (Z score) })\end{array}$ & $\begin{array}{l}\text { DMO } \\
\text { L1 - L4 } \\
\left(\mathrm{g} / \mathrm{cm}^{3}\right) \mathrm{v}\end{array}$ & $\begin{array}{l}\text { DMO - } \\
\text { CTsc } \\
\left(\mathrm{g} / \mathrm{cm}^{2}\right) \mathbf{a}\end{array}$ & $\begin{array}{l}\text { DMO - } \\
\text { CTsc } \\
\left(\mathrm{g} / \mathrm{cm}^{3}\right) \mathbf{v}\end{array}$ & $\begin{array}{c}\text { AMO } \\
(\%)\end{array}$ \\
\hline $\begin{array}{l}\text { Gordura } \\
\text { Corporal } \\
\text { Total (g) }\end{array}$ & $0,71^{*}$ & 0,34 & $0,56^{*}$ & $0,61 *$ & $0,82 *$ & 0,45 & $-0,21$ \\
\hline $\begin{array}{l}\text { Massa Magra } \\
\text { sem Osso (g) }\end{array}$ & $0,66^{*}$ & 0,22 & 0,31 & $0,54 *$ & $0,81 *$ & 0,43 & 0,22 \\
\hline $\begin{array}{l}\text { Massa Gorda } \\
\text { em Tronco (g) }\end{array}$ & $0,67 *$ & 0,36 & 0,48 & $0,57 *$ & $0,79 *$ & $0,52 *$ & $-0,36$ \\
\hline
\end{tabular}

Nota: Correlação de Spearman. DMO: Densidade mineral óssea, CT (SC): Corpo total sem cabeça AMO: Adiposidade da medula óssea.* $\mathrm{P}<0,05$.

A tabela 16 mostra que o GC não apresentou correlação entre tecido subcutâneo, gordura visceral e gordura hepática com massa óssea e adiposidade da medula óssea. Enquanto que a tabela 17 mostra que no GO houve correlação positiva da área subcutânea em $\mathrm{mm}^{2}$ com DMO em CTsc areal. Porém essa correlação desaparece quando a DMO areal é convertida a volumétrica.

Tabela 16: Correlação entre variáveis relativas à massa óssea, adiposidade da medula óssea e gordura visceral e hepática nos indivíduos do grupo controle. Valores expressos coeficiente de correlação (r).

\begin{tabular}{|c|c|c|c|c|c|c|c|}
\hline & $\begin{array}{c}\text { DMO } \\
\text { L1 - L4 } \\
\left(\mathrm{g} / \mathrm{cm}^{2}\right) \mathrm{a}\end{array}$ & $\begin{array}{c}\text { DMO } \\
\text { L1 - L4 } \\
\text { (Z score) }\end{array}$ & $\begin{array}{c}\text { DMO } \\
\text { L1 - L4 } \\
(\mathrm{Z} \text { score }) c\end{array}$ & $\begin{array}{c}\text { DMO } \\
\text { L1 - L4 } \\
\left(\mathrm{g} / \mathrm{cm}^{3}\right) \mathrm{v}\end{array}$ & $\begin{array}{c}\text { DMO - } \\
\text { CTsc } \\
\left(\mathrm{g} / \mathrm{cm}^{2}\right) \mathrm{a}\end{array}$ & $\begin{array}{c}\text { DMO - } \\
\text { CTsc } \\
\left(\mathrm{g} / \mathrm{cm}^{3}\right) \mathbf{v}\end{array}$ & $\begin{array}{r}\text { AMO } \\
(\%)\end{array}$ \\
\hline $\begin{array}{l}\text { Área subcutânea } \\
\qquad\left(\mathbf{m m}^{2}\right)\end{array}$ & 0,33 & $-0,14$ & $-0,18$ & 0,40 & $-0,012$ & $-0,23$ & 0,042 \\
\hline Área visceral $\left(\mathrm{mm}^{2}\right)$ & 0,039 & $-0,30$ & $-0,25$ & 0,18 & $-0,23$ & $-0,28$ & $-0,06$ \\
\hline $\begin{array}{c}\text { Gordura hepática } \\
(\%)\end{array}$ & $-0,11$ & 0,28 & 0,21 & $-0,34$ & 0,16 & 0,18 & 0,30 \\
\hline
\end{tabular}

Nota: Correlação de Spearman. DMO: Densidade mineral óssea, CT (SC): Corpo total sem cabeça AMO: Adiposidade da medula óssea.* $\mathrm{P}<0,05$. 
Tabela 17: Correlação entre variáveis relativas à massa óssea, adiposidade da medula óssea e gordura visceral e hepática nos indivíduos do grupo obeso. Valores expressos coeficiente de correlação (r).

\begin{tabular}{|c|c|c|c|c|c|c|c|}
\hline & $\begin{array}{c}\text { DMO } \\
\text { L1 - L4 } \\
\left(\mathrm{g} / \mathrm{cm}^{2}\right) \mathrm{a}\end{array}$ & $\begin{array}{c}\text { DMO } \\
\text { L1 - L4 } \\
\text { (Z score) }\end{array}$ & $\begin{array}{c}\text { DMO } \\
\text { L1 - L4 } \\
(\mathrm{Z} \text { score }) \text { c }\end{array}$ & $\begin{array}{c}\text { DMO } \\
\mathrm{L1}-\mathrm{L4} \\
\left(\mathrm{g} / \mathrm{cm}^{3}\right) \mathrm{v}\end{array}$ & $\begin{array}{l}\text { DMO - } \\
\text { CTsc } \\
\left(\mathrm{g} / \mathrm{cm}^{2}\right) \mathrm{a}\end{array}$ & $\begin{array}{c}\text { DMO - } \\
\text { CTsc } \\
\left(\mathrm{g} / \mathrm{cm}^{3}\right) \mathbf{v}\end{array}$ & $\begin{array}{r}\text { AMO } \\
(\%)\end{array}$ \\
\hline $\begin{array}{l}\text { Área subcutânea } \\
\qquad\left(\mathbf{m m}^{2}\right)\end{array}$ & 0,36 & 0,13 & 0,44 & 0,25 & $0,50 *$ & 0,17 & $-0,24$ \\
\hline Área visceral $\left(\mathrm{mm}^{2}\right)$ & 0,033 & $-0,23$ & $-0,10$ & 0,032 & 0,24 & $-0,22$ & 0,10 \\
\hline $\begin{array}{c}\text { Gordura hepática } \\
(\%)\end{array}$ & $-0,19$ & 0,04 & $-0,18$ & $-0,16$ & $-0,01$ & $-0,23$ & 0,18 \\
\hline
\end{tabular}

Nota: Correlação de Spearman. DMO: Densidade mineral óssea, CT (SC): Corpo total sem cabeça AMO: Adiposidade da medula óssea.* $\mathrm{P}<0,05$.

A tabela 18 mostra um modelo de regressão linear, onde apenas o IMC apresentou associação positiva com com a DMO em L3 com significância estatística.

Tabela 18: Modelo de regressão linear: associação da AMO, IGF1R, IGF-I e IMC com DMO em L3.

\begin{tabular}{ccccc} 
Variável & Estimativa & IC 95\% & p-valor & $\mathbf{r}^{\mathbf{2}}$ \\
\hline AMO x DMO-L3 & $-0,0007$ & $(-0,003 ; 0,001)$ & 0,45 & 0,02 \\
\hline IGFIRc x DMO-L3 & 0,23 & $(-0,19 ; 0,65)$ & 0,28 & 0,04 \\
\hline IGFIc x DMO-L3 & $-0,02$ & $(-0,05 ; 0,007)$ & 0,15 & 0,07 \\
\hline IMC x DMO-L3 & 0,003 & $(0,001 ; 0,004)$ & $<0,01$ & 0,34
\end{tabular}

Nota: Regressão linear. DMO: Densidade mineral óssea, AMO: Adiposidade da medula óssea. ${ }^{*} \mathrm{P}<0,05$. 


\section{DISCUSSÃO}

O sobrepeso e a obesidade vêm tomando proporções globais cada vez maiores tanto em adultos, quanto em crianças, sendo considerados uma pandemia mundial (Roth et al., 2004; Swinburn et al., 2011). Dados de 2010 apontam que o sobrepeso e a obesidade foram responsáveis por cerca de 3,4 milhões de mortes no mundo (Lim et al., 2012). A obesidade é uma doença crônica não transmissível associada a uma série de comorbidades. Há quem defina essa doença como um distúrbio do metabolismo energético que apresenta como consequência um excessivo acúmulo de gordura corpórea, com graves complicações orgânicas e psicossociais (Laquatra, 2005). Hoje sabemos que o peso corporal tem estreita correlação com a massa óssea em seres humanos (Reid et al., 1994).

Os resultados deste trabalho dão suporte aos estudos mencionados acima, mostrando que crianças obesas apresentam massa óssea significativamente maior do que crianças com peso normal. Ainda, a importância do peso na determinação da massa óssea foi ressaltada ao se observar que as diferenças persistem significativas após a correção da medida de massa óssea para idade óssea e para valores volumétricos.

Cobayashi e colaboradores avaliaram em um estudo caso-controle, 172 adolescentes com idades entre 14 e 19 anos, sendo 83 com sobrepeso ou obesos e 89 controles. Os mesmos observaram que a massa óssea de corpo total e coluna lombar (L2-L4) apresentou-se maior entre os adolescentes com sobrepeso ou obesidade (Cobayashi et al., 2005). Dados semelhantes foram observados neste estudo; os 15 indivíduos obesos com idade entre 10 a 17 anos, apresentaram DMO em g/ $\mathrm{cm}^{2}$, tanto em coluna lombar (L1-L4) quanto em L3 isoladamente mais elevada que o GC. Um dado interessante foi o ajuste dos valores da DMO de $\mathrm{g} / \mathrm{cm}^{2}$ para $\mathrm{g} / \mathrm{cm}^{3}$, uma vez que a medida da densidade de massa óssea areal sofre influência significativa do tamanho do osso (Carter et al., 1992). Este ajuste fez com que diminuísse a diferença entre a massa óssea dos dois grupos, porém o GO manteve a massa óssea maior. Estes dados reforçam a importância da realização de ajustes da DMO areal para volumétrica, assim como para idade óssea em crianças e adolescentes.

Nos últimos anos, surgiu grande interesse no estudo do papel da redistribuição de gordura sobre o tecido ósseo. Alguns autores apontam ser a massa magra o principal elemento envolvido no metabolismo ósseo, enquanto outros sugerem ser a massa gorda o componente de maior impacto sobre a massa óssea (Raisz, 2005). Sabe-se que inúmeros fatores nutricionais, hormonais, ambientais e genéticos interferem no desenvolvimento ósseo, influenciando de diversas maneiras sobre a qualidade e quantidade de massa óssea. Desta forma, o tecido adiposo apresenta estreita ligação com a massa óssea, uma vez que, não exerce 
apenas função de armazenamento, mas também endócrina. Sendo assim, ainda está por se elucidar qual componente corporal tem maior impacto sobre a massa óssea. Neste trabalho observou-se correlação entre a DMO e composição corporal nos dois grupos. O grupo controle apresentou correlação positiva da massa óssea em L1-L4 e CTsc tanto com a gordura corporal quanto com a massa magra. O grupo obeso também mostrou essa correlação positiva da DMO com a composição corporal, porém mais forte que o grupo controle, reforçando que tanto o tecido adiposo quanto o tecido muscular podem ter influência positiva sobre a massa óssea (Reid,1994; Reid 2002).

O papel que o tecido adiposo exerce sobre o tecido ósseo passou a ser alvo de grande interesse de estudo. A ideia inicial que a obesidade teria efeito protetor sobre a suscetibilidade a fraturas foi desfeita a partir de estudos que mostraram que a ocorrência de fraturas na população obesa é igual ou maior do que na população com peso normal. Com toda probabilidade esta revelação indica que a obesidade deve ter papel deletério sobre a qualidade óssea. No entanto, do ponto de vista clínico a medida da DMO não deve ser desprezada, visto que estudos posteriores mostraram que entre os obesos há mais fraturas naqueles com menor DMO (Premaor et al.,2014; Prieto-Alhambra et al., 2012). Na linha de estudos de avaliação de ocorrências de fraturas relacionadas a obesidade, a maior suscetibilidade a fraturas nesta condição, foi observada em crianças por Gouding et al (Goulding et al., 2005; Davidson et al., 2003; ).

Desde a década de 90, diversos estudos mostraram que não só a quantidade de gordura corporal, mas também a sua distribuição, contribui para o surgimento de doenças metabólicas como resistência a insulina, diabetes mellitus, hipertensão arterial sistêmica e doenças cardiovasculares. A partir desses estudos ficou claro que a gordura visceral tem papel deletério, sendo fonte importante de fatores inflamatórios e de maior atividade lipolítica, gerando um estado inflamatório crônico e lipotoxicidade. Desde então, passou a ser obrigatório, em estudos de associação entre obesidade com outras doenças, a avaliação do papel da distribuição da gordura corporal. Referente a massa óssea, a relação da distribuição da gordura corporal com o risco de osteoporose ainda não está bem estabelecida, existindo resultados conflitantes quanto a este aspecto (Ribeiro Filho et $a \mathrm{l}$. 2006) .

No presente estudo mostrou que a gordura visceral não se correlacionou com DMO no GC. Da mesma forma, o GO também não mostrou essa relação e de maneira curiosa, este grupo revelou associação positiva do tecido subcutâneo (área subcutânea) com a DMO em CTsc areal.

Neste sentido, Bredella et al mostraram que o tecido visceral tem relação negativa com a massa óssea em mulheres adultas obesas pré-menopausa (Bredella et al., 2011). Outro estudo que mostrou correlação negativa entre gordura visceral e DMO, foi o realizado por Campos et al. Neste estudo, os 
autores estudaram 125 adolescentes obesos púberes com idades entre 14 a 18 anos (Campos et al., 2012). Esses dados também foram reproduzidos por Russel et al, ao mostrarem que o tecido adiposo visceral em meninas adolescentes obesas, se associa negativamente com a massa óssea (Russel et al., 2010). Em contrapartida, o presente estudo, realizado com crianças e adolescentes obesos de ambos os sexos, não mostrou relação entre tecido visceral e DMO, apesar do grupo obeso apresentar valores maiores tanto da gordura visceral quanto hepática. É possível que a grande controvérsia que existe entre relação da gordura sobre o tecido ósseo, pelo menos em parte, seja devido a diferença de resultados obtidos por técnicas diferentes.

Escassa ao nascimento, a AMO surge durante o desenvolvimento e progride constantemente com o envelhecimento. Tem sido sugerido que a gordura da medula óssea tem papel de sustentação energética durante a fase de crescimento, período de anabolismo ósseo (Kawai et al., 2012). Enquanto isto, após o amadurecimento e em condições patológicas, possivelmente a expansão da AMO ocorre em detrimento da formação óssea. Nesta última condição, o entendimento é que osteoblastos e adipócitos compartilham origem comum a partir de uma mesma célula tronco mesenquimal, assim a diferenciação da célula tronco da medula óssea em adipócitos ocorre às custas da diminuição da diferenciação para osteoblastos. Durante a menopausa e na osteoporose induzida por glicocorticóide estudos prévios sugerem que a perda de massa óssea se associa com aumento de adiposidade de medula óssea (Rosen, 2006). Nesta linha de pesquisa, chama atenção que a restrição alimentar em estudos experimentais e na anorexia nervosa, onde há auto-imposição de jejum, há aumento da AMO e associação negativa entre AMO e DMO. Portanto, o comportamento da AMO diverge do padrão apresentado pelo tecido adiposo branco, o qual expande em condições de excesso de calorias e reduz drasticamente na escassez de alimentos. Há poucos estudos na literatura sobre a AMO na obesidade, em particular em crianças e adolescentes.

O presente estudo mostrou que tanto o GC quanto o GO não apresentaram correlação entre DMO e AMO. Semelhante aos nossos resultados , um estudo recente de Araujo et al, ao avaliarem 24 indivíduos controles, 26 obesos e 28 com diabetes tipo2, também não mostraram haver associação entre DMO e AMO entre esses grupos (de Araújo et al., 2017)

No entanto, comparando a relação entre DMO e AMO em crianças e adultos saudáveis Shen et al encontraram correlações negativas da DMO com a AMO em ambos os grupos. Há de se ressaltar que os autores descreveram como limitações a utilização da região pélvica para avaliar DMO e AMO. Sabendo que o acúmulo ósseo e a gordura medular óssea varia de acordo com a região corporal e com a idade, o mesmos autores destacam a necessidade de mais estudos avaliando a DMO em outras regiões 
como coluna vertebral e colo do fêmur, já que essas regiões são utilizadas para o diagnóstico de osteoporose. Ainda nesse estudo, os autores sugerem o uso da recente metodologia de espectroscopia de $\mathrm{H}^{1}$ aplicada à ressonância magnética para quantificar a $\mathrm{AMO}$, especialmente em crianças, como realizado no presente estudo (Shen et al., 2014).

Ao avaliarem 31 mulheres não diabéticas, porém 11 dessas com resistência a insulina, de Paula et al em 2015, observaram que houve correlação negativa da DMO com AMO, apesar desse mesmo grupo não apresentarem correlação da AMO com a gordura visceral ou lipídios intra-hepáticos. Esses dados chamam atenção novamente para a importância da avaliação não somente da gordura corporal influenciando a massa óssea, mas também a sua distribuição, incluindo a AMO (de Paula et al., 2015)

A AMO foi considerada até pouco tempo atrás, apenas uma ocupação do espaço medular ósseo. Porém, essa quantidade de gordura tem sido apontada, cada vez mais, como modulador da homeostase dos ossos, uma vez que adipócitos e osteoblastos tem origem comum nas células-tronco mesenquimais. Em nosso estudo, apesar de ter havido discreta diferença da DMO em g/ $\mathrm{cm}^{3}$ entre GC e GO, ao avaliarmos a AMO por meio de RM, os grupos não apresentaram diferença significativa, chamando atenção para a idéia de que em crianças e adolescentes, apesar do ganho de peso corporal, não há aumento da gordura intramedular. Nossos dados levantam a hipótese de que a gordura medular óssea possa exercer funções conflitantes em diferentes fases da vida. A avaliação da DMO da vértebra L3 foi importante pois permitiu uma melhor comparação com a porcentagem de AMO, uma vez que foi utilizada a técnica de espectroscopia de $\mathrm{H}^{1}$ por RM em L3, como descrito anteriormente.

Uma vez que o estado nutricional pode interferir no sistema GH-IGF, surge o interesse em avaliar esse sistema em pacientes obesos. Até o momento a literatura se divide em resultados conflitantes sobre a secreção de GH e IGF-I nesse grupo de pacientes, em especial crianças e adolescentes. Pouco se sabe também sobre a influência do IGF-I, IGFBP3 e expressão do gene do IGF1R sobre a gordura óssea e massa óssea de Crianças e Adolescentes Obesos.

Este estudo não mostrou diferença nas concentrações de IGF-I, IGFBP-3 e IGF1R entre o GC e GO. Em partes houve controvérsia em relação ao estudo de Ricco et al, que mostraram haver maiores concentrações de IGF-I e expressão do IGF1R em crianças obesas. Porém, os indivíduos estudados por Ricco et al eram crianças obesas pré-puberes e com estatura elevada para metade superior do canal familiar. Além de também não terem sido correlacionados sistema GH-IGF-I e metabolismo ósseo nessa amostra. (Ricco et al., 2017). 
Em contra partida, Bredella et al mostraram a infuência do IGF-I na regulação da homeostase óssea em 39 mulheres obesas pré-menopausadas, que receberam GH por 6 meses, comparadas com 40 que receberam placebo. O grupo que recebeu GH obteve aumento de IGF-I, assim como da AMO e da DMO. (Bredella et al., 2014)

Apesar dos dados obtidos não mostrarem diferença nas concentrações de IGF-I, IGFBP-3 circulantes e IGF1R entre o GC e GO, houve correlação negativa do IGF-I com a DMO em CTsc areal e volumétrica no GC e correlação positiva do IGFBP-3 com a DMO areal no GO. Esses dados sugerem que a massa óssea em crianças e adolescentes esteja mais relacionada ao IGF-I local (autócrino /parácrino) do que com o sistêmico. Entretanto, mais estudos são necessários para esclarecer a real participação do sistema GH-IGF no metabolismo ósseo, em especial de crianças e adolescentes obesos. 


\section{CONCLUSÃO}

A comparação entre crianças e adolescentes eutróficos (GC) com indivíduos obesos (GO), permitiu concluir que:

$\checkmark$ Não houve diferença significativa em relação a AMO.

$\checkmark$ Houve diferença quanto a DMO em coluna lombar (L1-L4) e L3, quando os valores são expressos em areal e volumétrica.

$\checkmark$ Houve diferença quanto a DMO em coluna lombar (L1-L4) e L3, quando os valores são expressos em Z-score Z-score corrigido para idade óssea.

$\checkmark$ Não houve correlação entre os valores de AMO e DMO no GC e nem no GO.

$\checkmark$ Não houve diferença em relação às concentrações séricas de IGF-I e IGFBP-3.

$\checkmark$ Não foi observada diferença na expressão do mRNA do IGF1R.

$\checkmark$ Não foi constatada correlação entre os valores de AMO ou DMO e os valores de IGF-I, IGFBP-3 e s expressão do IGF1R. A participação do sistema IGF (IGF-I, IGFBP-3 e IGF1R) na determinação dos achados de DMO parece relacionar-se a sua ação autocrina/paracrina.

$\checkmark$ Houve correlação positiva entre os valores de DMO e Gordura Corporal Total, Massa Magra sem Osso e Massa Gorda em tronco tanto no GC quanto no GO. Estas correlações foram mais forte do GO. O GO apresentou também correlação positiva entre os valores de DMO e área de gordura subcutânea. 
REFERÊNCIAS BIBLIOGRÁFICAS 


\section{REFERÊNCIAS BIBLIOGRÁFICAS}

AMADEI, SU. et al. A influência estrogênica no processo de remodelação e reparação óssea. Bras Patol Med Lab. v. 42 , n. 1, p. 5-12, 2006.

BAXTER, R.C. et al.. Structure of the Mr 140,000 growth hormone dependent insulin-like growth factor binding protein complex: determination by reconstitution and affinity-labeling. Proc Natl Acad Sci .v.86, p. 6898-6902, 1989.

BORELLI, A. Envelhecimento ósseo: osteoporose. In: Filho ETC, Netto MP. Geriatria -Fundamentos, clínica e terapêutica. $1^{\text {a } e d . ~ S a ̃ o ~ P a u l o: ~ A t h e n e u . ~ V .22, ~ p . ~ 297-307,2000 . ~}$

BREDELLA, M. A. et al. Determinants of bone mineral density in obese premenopausal women. Bone. v.48, n. 4 , p.748-54,2011.

BREDELLA MA, GERWECK AV, BARBER LA. et al. Effects of growth hormone administration for 6 months on bone turnover and bone marrow fat in obese premenopausal women. Bone. 2014 May;62:29-35.

CAMPOS LM, LIPHAUS BL, SILVA CA, PEREIRA RM. Osteoporosis in childhood andadolescence. J Pediatr (Rio J). 2003 Nov-Dec;79(6):481-8.

CAMPOS, R.M.S. et al. Influence of visceral and subcutaneous fat in bone mineral density of obese adolescents. Arq Bras Endocrinol Metab. v. 56, n. 1, p.12-18, 2012.

CARTER, D.R. et al. New approaches for interpreting projected bone densitometry data. Journal of Bone and Mineral Research. V.7, p. 137-145, 1992.

CASSIDY, J.T. Osteopenia and osteoporosis in children. ClinExpRheumatol. v.17, p.245-250, 1999.

CHEUNG PC, CUNNINGHAM SA, NARAYAN KM, KRAMER MR. Childhood Obesity Incidence in the United States: A Systematic Review. Child Obes. 2016 Feb;12(1):1-11.

COBAYASHI, F. et al. Densidade óssea de adolescentes com sobrepeso e obesidade. Jornal de Pediatria. v. 81, n.4, 2005.

CUNNINGHAM SA, KRAMER MR, NARAYAN KM. Incidence of childhood obesity in the United States. N Engl J Med. 2014 Jan 30;370(5):403-11.

CHEUNG PC, CUNNINGHAM SA, NARAYAN KM, KRAMER MR. Childhood Obesity Incidence in the United States: A Systematic Review. Child Obes. 2016 Feb;12(1):1-11. 
DAVIDSON PL, GOULDING A, CHALMERS DJ. Biomechanical analysis of arm fracture in obese boys. J Paediatr Child Health. 2003 Dec;39(9):657-64.

DE ARAÚJO IM, SALMON CE, NAHAS AK, NOGUEIRA-BARBOSA MH, ELIAS J JR, DE PAULA FJ. Marrow adipose tissue spectrum in obesity and type 2 diabetes mellitus. Eur J Endocrinol. 2017 Jan;176(1):21-30.

DE PAULA FJ, DE ARAÚJO IM, CARVALHO AL, ELIAS J JR, SALMON CE, NOGUEIRA-BARBOSA MH. The Relationship of Fat Distribution and Insulin Resistance with Lumbar Spine Bone Mass in Women. PLoS One. 2015 Jun $11 ; 10(6)$

DE PAUlA FJ, ROSEN CJ. Bone Remodeling and Energy Metabolism: New Perspectives. Bone Res. 2013 Mar 29;1(1):72-84.

ERIKSEN, E. F. et al. Evidence of estrogen receptors in normal human osteoblas-like cells. Science, v.241, p. 84$6,1988$.

GIUSTINA A, MAZZIOTTI G, CANALIS E. Growth hormone, insulin-like growth factors, and the skeleton. Endocr Rev. 2008 Aug;29(5):535-59.

GOULDING A, GRANT AM, WILLIAMS SM. Bone and body composition of children and adolescents with repeated forearm fractures. J Bone Miner Res. 2005.Dec;20(12):2090-6.

JOGREN, K. et al. Liver-derived insulin-like growth factor I (IGF-I) is the principal source of IGF-I in blood but is not required for postnatal body growth in mice. Proc Natl Acad Sci. v.96, p. 7088-7092, 1999.

JONES, J.I., Clemmons D.R. Insulin-like growth factors and their binding proteins: biological actions. Endocr Rev. v.16, n.1, p.3-34, 1995.

KANIS, J.A. et al. FRAX and the assessment of fracture probability in men and women from the UK. Osteoporos Int. v. 19, n. 4, p.385-397, 2008.

KAWAI, M., De Paula F. J., et al. New insights into osteoporosis: the bone-fat connection. J Intern Med, v.272, n.4, p.317-329, 2012.

KOHLI SS, KOHLI VS. Role of RANKL-RANK/osteoprotegerin molecular complex in bone remodeling and its immunopathologic implications. Indian J Endocrinol Metab. 2011 Jul;15(3):175-81.

LAQUATRA, I.M. Nutrição Para o Controle de Peso. Alimentos, Nutrição \& Dietoterapia, $11^{a}$ ed. São Paulo: Editora Roca. P.541-67, 2005.

LIMA, F. et al. Effect of impact load and active load on bone metabolism and body composition of adolescent athletes. Med Sci Sports Exerc. V.33, n.8, p. 18-23, 2001.

LIM, S.S. et al. A comparative risk assessment of burden of disease and injury attributable to 67 risk factors and risk factor clusters in 21 regions, 1990-2010: a systematic analysis for the Global Burden of Disease Study 2010. The Lancet. V.380, p. 2224-2260, 2012. 
LOPES, Renata Francioni; FARIAS, Maria Lucia Fleiuss de. Aspectos genéticos, influência do eixo GH/IGF1 e novas possibilidades terapêuticas na osteoporose idiopática. Rev. Bras. Reumatol., São Paulo, v. 46, n. 2, p. 110 117, abr. 2006.

MARTINELLI CE JR, CUSTÓDIO RJ, AGUIAR-OLIVEIRA MH. Physiology of the GH-IGF axis. Arq Bras Endocrinol Metabol. 2008 Jul;52(5):717-25.

MARTINELLI, C.E. et al. Crescimento normal: avaliacao e regulacao endocrina.In: Antunes-Rodrigues J,Moreira AC, Elias LLK, Castro M, editores. Neuroendocrinologia básica e aplicada. Rio de Janeiro: Guanabara Koogan; p. 366-389, 2005.

MARUI, S. et al. Bases Genéticas dos Distúrbios de Crescimento.Arq Bras Endocrinol Metab . vol.46, n.4, p.444456, 2002.

MELLO E. D. et al.Childhood obesity Towards effectiveness. J Pediatr. V.80, n.3, p.173-182, 2004.

PREMAOR, M. O., L. Pilbrow, et al. Obesity and fractures in postmenopausal women. J Bone Miner Res, v.25, n.2, p.292-297, 2014.

PRIETO-ALHAMBRA, D. et al.The association between fracture and obesity is site-dependent: a populationbased study in postmenopausal women. J Bone Miner Res. v.27, n.2, p.294-300, 2012.

RAISZ, L.G. Pathogenesis of osteoporosis: concepts,conflicts, and prospects.The Journal Clinical Investigation.v.115.Dec.2005.

REID, I.R. et al. Volumetric bone density of the lumbar spine is related to fat mass but not lean mass in normal postmenopausal women. Osteoporos Int. v. 4, p. 362-367, 1994.

REID, I.R. Fat and bone.ArchBiochemBiophys. v.503, n.1, p.20-27, 2010.

RIBEIRO FILHO, Fernando F. et al . Gordura visceral e síndrome metabólica: mais que uma simples associação. Arq Bras Endocrinol Metab, São Paulo, v. 50, n. 2, p. 230-238, Apr. 2006

RIGGS, BL, Melton LJ. Involutional osteoporosis.N Engl J Med. v.314, p. 676-86, 1986.

RICCO RC, RICCO RG, DE PAULA MT., et al. IGF1R mRNA expression is increased in obese children. Growth Hormone \& IGF Research (in press); 2017.

ROSEN, C. J. e Bouxsein M.L.Mechanisms of disease: is osteoporosis the obesity of bone? Nat Clin Pract Rheumatol, v.2, n.1, p.35-43. 2006.

ROSENFELD, R.G, Cohen P. Disorders of growth hormone/insulinlike growth factor secretion and action. In: Sperling MA, editores.Pediatric endocrinology. 2nd ed. Philadelphia: Saunders; p. 211-288, 2002.

ROTH, J. et al. The Obesity Pandemic: Where Have We Been and Where Are We Going? Obes Res. V.12, p.8851015, 2004. 
RUSSELL, M. et al. Visceral Fat Is a Negative Predictor of Bone Density Measures in Obese Adolescent Girls. The Journal of Clinical Endocrinology and Metabolism. v. 95, n. 3, p. 1247-1255, 2010.

SHEN W, VELASQUEZ G, CHEN J, JIN Y, HEYMSFIELD SB, GALLAGHER D, PI-SUNYER FX. Comparison of the relationship between bone marrow adipose tissue and volumetric bone mineral density in children and adults. J Clin Densitom. 2014 Jan-Mar;17(1):163-9.

SWINBURN, BA. et al. The global obesity pandemic: shaped by global drivers and local environments.

The Lancet.v. 378, p.804-814, 2011.

TURNER, R.T; Riggs,B.L;Spelsberg,T.C.Skeletal effects of estrogen. Endocrine Rev, v. 15, n. 3, p. 275-300, 1994.

TSATSOULIS A, MANTZARIS MD, BELLOU S, ANDRIKOULA M. Insulin resistance: anadaptive mechanism becomes maladaptive in the current environment - an evolutionary perspective. Metabolism. 2013 May;62(5):622-33.

UNDERWOOD, L. E. et al. Normal and aberrant growth. In:Wilson JD, Foster DW, editores. Willians - Textbook of endocrinology.7th ed. Philadelphia: Saunders. p. 155-205, 1985.

VAN DER SLUIS,I.M, MuinckKeizer-Schrama S.M.P.F. Osteoporosisin childhood: bone density in children in health and disease. J PediatrEndocrinolMetab.v.14, p.817-832,2001.

ZEMEL B. Bone mineral accretion and its relationship to growth, sexual maturation and body composition during childhood and adolescence. World Rev Nutr Diet. 2013;106:39-45.

ZMUDA JM, CAULEY JA, FERRELL RE. Recent progress in understanding the genetic susceptibility to osteoporosis. Genet Epidemiol. 1999;16(4):356-67. 
ANEXOS 


\section{ANEXOS}

Anexo 1: Fluxograma

CASUÍSTICA

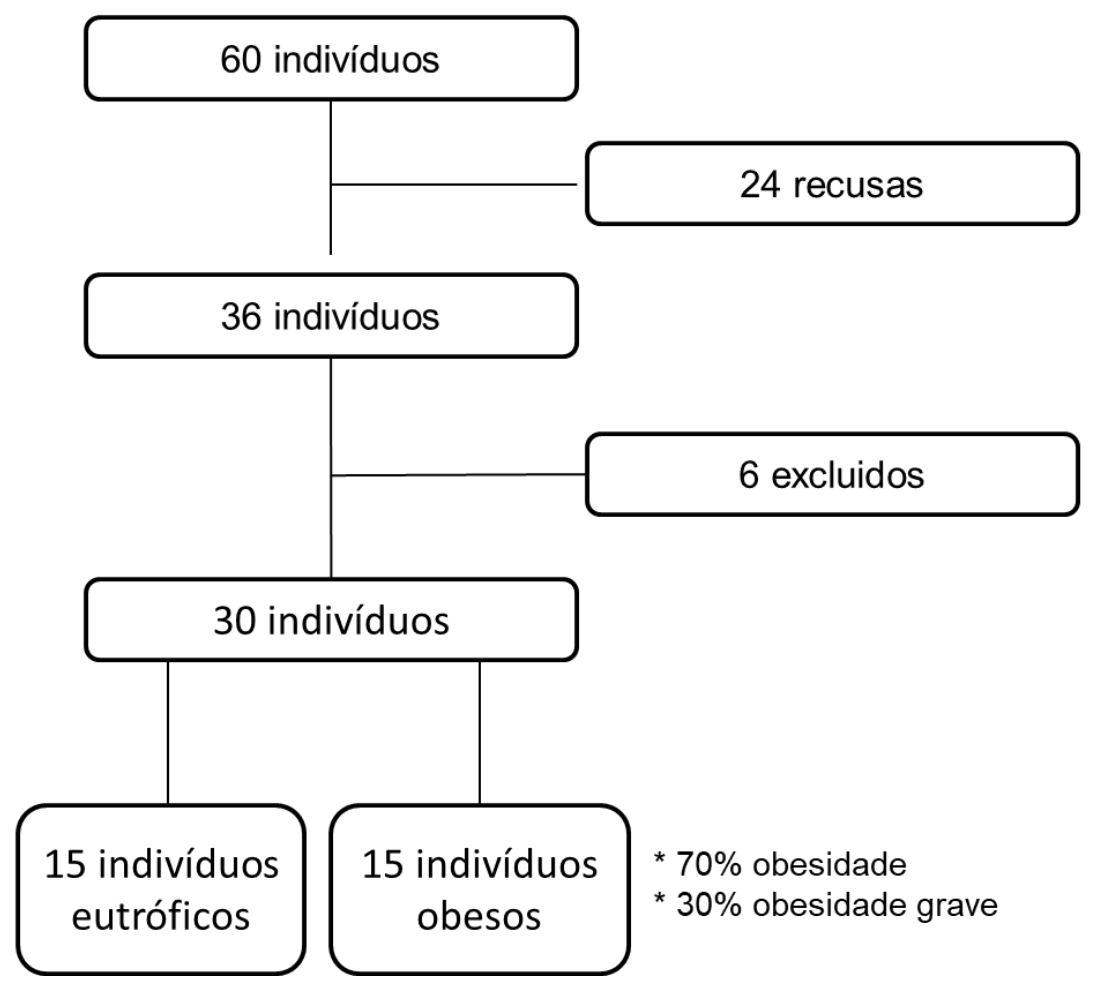


Anexo 2: Termo de Assentimento e Termo de Consentimento Livre e Esclarecido

\title{
TERMO DE ASSENTIMENTO
}

\author{
HOSPITAL DAS CLÍNICAS FACULDADE DE MEDICINA DE RIBEIRÃO PRETO-USP \\ DEPARTAMENTO DE PEDIATRIA E PUERICULTURA
}

\author{
AUTORIZAÇÃO PARA PARTICIPAR EM PROJETO DE PESQUISA
}

Você está sendo convidado para participar da pesquisa Estudo da Associação do Tecido Adiposo Medular Ósseo, Massa Óssea e a Expressão do Receptor tipo 1 dos IGFs em Crianças e Adolescentes Obesos. Seus pais permitiram que você participe. Queremos saber a influência da obesidade na saúde óssea(massa óssea e gordura óssea). Para isso, serão avaliados a composição e metabolismo ósseos em crianças e adolescentes obesos e comparar com a composição e metabolismo ósseos em crianças e adolescentes não obesos..As crianças que irão participar dessa pesquisa terão de 8 a 18 anos de idade e serão diagnosticadas como obesas ou não obesas.. Você não precisa participar da pesquisa se não quiser, é um direito seu, não terá nenhum problema se desistir. A pesquisa será feita nos Ambulatórios de Endocrinologia do HCFMRP-USP e nos Ambulatórios de Pediatria e Puericultura do Centro Médico Comunitário da Vila Lobato. Ambos locais em Ribeirão Preto-SP. Se você for um indivíduo que preencha os critérios para inclusão no estudo, será colhido $10 \mathrm{ml}$ de sangue da veia do seu braço, equivalente a aproximadamente duas colheres de sopa. A realização desse exame é segura, mas é possível que a picada da agulha possa causar uma dor passageira e você poderá ter uma mancha e dor no local por alguns dias. Também serão feitos exame de densitometria óssea de corpo total e coluna lombar e ressonância magnética de coluna lombar e fígado. Estes exames não causam dor,porém,algumas pessoas não suportam ficar em ambiente fechado e por isso não conseguem realizar exame de ressonância magnética. Todos os exames serão supervisionados por, pelo menos, um pesquisador deste estudo. A sua participação poderá ajudar outros indivíduos no futuro com os resultados e conhecimentos obtidos a partir deste estudo.Caso aconteça algo errado, você pode nos procurar pelos telefone (16) 3602-2575 da pesquisadora Emiliana Ribeiro Darrigo. Ninguém saberá que você está participando da pesquisa, não falaremos a outras pessoas, nem daremos a estranhos as informações que você nos der. Os resultados da pesquisa vão ser publicados, mas sem identificar as crianças ou adolescentes que participaram da pesquisa. Se você tiver alguma dúvida, você pode me perguntar agora ou pelo telefone citado na parte de cima desse texto. Eu aceito participar da pesquisa Associação do Tecido Adiposo Medular Ósseo, Massa Óssea e as Concentrações Séricas do Fator de Crescimento Insulina Símile tipo 1( IGF-I) e a Expressão do Receptor Tipo 1 dos Fatores de Crescimento Insulina Símile( IGF1R) em Crianças e Adolescentes Obesos, que tem como objetivo avaliar a influência da obesidade na saúde óssea(massa óssea e gordura óssea) de crianças e adolescentes obesos, comparado com pacientes não obesos. Entendi as coisas ruins e as coisas boas que podem acontecer. Entendi que posso dizer "sim" e participar, mas que, a qualquer momento, posso dizer "não" e desistir que ninguém vai ficar furioso. Os pesquisadores tiraram minhas dúvidas e conversaram com os meus responsáveis. Recebi uma cópia deste termo de assentimento e li e concordo em participar da pesquisa.

Assinatura do menor alfabetizado

Ribeirão Preto, de de 


\title{
TERMO DE CONSENTIMENTO LIVRE E ESCLARECIDO
}

\author{
UNIVERSIDADE DE SÃO PAULO \\ HOSPITAL DAS CLÍNICAS FACULDADE DE MEDICINA DE RIBEIRÃO PRETO \\ DEPARTAMENTO DE PEDIATRIA E PUERICULTURA
}

AUTORIZAÇÃO PARA PARTICIPAR EM PROJETO DE PESQUISA

\begin{abstract}
TÍTULO DO ESTUDO: Estudo da Associação do Tecido Adiposo Medular Ósseo, Massa Óssea e a Expressão do Receptor tipo 1 dos IGFs em Crianças e Adolescentes Obesos
\end{abstract}

\section{DATA DO CONSENTIMENTO:}

\author{
PESQUISADORES RESPONSÁVEIS: \\ Prof. Dr. Francisco José de Paula Albuquerque \\ Prof. Dr. Carlos Eduardo Martinelli Junior \\ Emiliana Ribeiro Darrigo
}

\section{NOME DO VOLUNTÁRIO:}

O (a) seu filho (a) está sendo convidado para ser voluntário em um estudo de pesquisa clínica. Os estudos de pesquisa clínica incluem apenas pessoas que aceitam participar voluntariamente. A decisão de participação na pesquisa deverá ser feita após o (a) seu filho (a) ter pleno conhecimento sobre os riscos e benefícios envolvidos e então tomar um decisão que lhe seja adequada. Este processo é conhecido como consentimento informado. Por favor, reflita para tomar uma decisão.

O (a) seu filho (a) está sendo convidado para participar deste estudo porque o (a) seu filho(a) preenche os critérios de inclusão da pesquisa.

\section{POR QUE ESTE ESTUDO SERÁ REALIZADO?}

Esta pesquisa está sendo feita para avaliar a composição e metabolismo ósseos em crianças e adolescentes obesos e comparar com a composição e metabolismo ósseos em crianças e adolescentes não obesos.O objetivo desse estudo é analisar a influência da obesidade na saúde óssea(massa óssea e gordura óssea).

\section{QUAIS INDIVÍDUOS FARÃO PARTE DESTE ESTUDO CLÍNICO?}

Serão avaliados indivíduos entre 8 e 18 anos de idade com diagnóstico de obesidade atendidos nos Ambulatórios de Endocrinologia do HCFMRP-USP e indivíduos não obesos atendidos nos ambulatórios de Pediatria e Puericultura do Centro Médico Comunitário da Vila Lobato. Ambos locais em Ribeirao Preto-SP.

\section{O QUE ESTÁ ENVOLVIDO NESTE ESTUDO?}

Se o (a) seu filho (a) participar deste estudo clínico, será colhido $10 \mathrm{ml}$ de sangue, equivalente a aproximadamente duas colheres de sopa. Isto envolve uma picada com agulha na veia do braço do (a) seu filho (a ). Esta coleta pode ser realizada quando lhe for conveniente. Também serão feitos exame de densitometria óssea de corpo total e coluna lombar e de ressonância magnética de coluna 
lombar e fígado. Estes exames não causam dor, porém algumas pessoas sentem desconforto em exame de ressonância magnética devido ao ambiente fechado. A quantidade de raios-X emitida nos exames de densitometria óssea e coluna vertebral são pequenas, pois os aparelhos utilizados reduzem a exposição a radiação. Todos os exames serão supervisionados por, pelo menos, um pesquisador deste estudo, estando o(a) seu filho(a) sob os cuidados de um médico, caso seja necessário alguma intervenção de emergência.

\section{QUANTO TEMPO VOCÊ ESTARÁ PARTICIPANDO DESTE ESTUDO DE PESQUISA?}

Os exames serão realizados apenas uma vez durante o estudo.

\section{QUAIS OS RISCOS DESTE ESTUDO DE PESQUISA?}

Os riscos neste estudo de pesquisa são relacionados a coleta de sangue da sua veia, e exames de imagem. A picada da agulha pode causar uma dor passageira e o (a) seu filho(a) poderá ter uma mancha e dor no local por alguns dias. Como referido acima, os outros exames não causam dor. Algumas pessoas não suportam ficar em ambiente fechado e por isso não consegue realizar exame de ressonância magnética.

\section{EXISTEM BENEFÍCIOS EM PARTICIPAR DESTE ESTUDO CLÍNICO?}

Não existem benefícios direto para o (a) seu filho(a) em participar deste estudo de pesquisa. Porém, sua participação poderá ajudar outros indivíduos no futuro com os resultados e conhecimentos obtidos a partir deste estudo.

\section{QUAIS AS OUTRAS OPÇÕES QUE EXISTEM?}

$\mathrm{O}$ (a) seu filho(a) pode decidir por não participar desse estudo e não terá nenhum efeito sobre qualquer aspecto em atendimento no HC-FMRP.

\section{SOBRE A CONFIDENCIALIDADE?}

Esforços serão feitos para manter suas informações pessoais confidenciais. Os resultados dos testes realizados com o sangue e /ou urina do(a) seu filho(a) serão mantidos completamente anônimo e confidencial. Os resultados serão mantidos em segurança em computadores protegidos por senha. Todas as informações serão codificadas e nenhum identificador pessoal será armazenado.

\section{QUAIS SÃO OS CUSTOS?}

Não existe nenhum custo para o (a) seu filho(a) se o (a) seu filho(a) participar deste estudo.

\section{QUAIS SÃO OS MEUS DIREITOS COMO UM PARTICIPANTE?}

Fazer parte deste estudo é uma escolha sua. Você pode escolher não participar ou pode deixar de participar do estudo a qualquer momento. Deixar de participar do estudo não resultará em nenhuma penalidade ou perda de benefícios que o (a) senhor (a) tem direito.

\section{PERMISSÃO PARA O USO DOS RESULTADOS DA PESQUISA}

\section{POR QUE EU ESTOU SENDO QUESTIONADO PARA LIBERAÇÃO DESTA INFORMAÇÃO?}

Como parte deste estudo, o (a) seu filho(a) está sendo solicitado a permitir a pesquisadora Emiliana Ribeiro Darrigo a coletar informação sobre a sua saúde. Esta informação será coletada, listada em um banco de dados com informação de saúde de todos os participantes deste estudo, e analisada para identificar correlações entre os achados. 


\section{O QUE ESTA SENDO SOLICITADO PARA LIBERAÇÃO?}

Para este estudo, as seguintes informações serão coletadas:

Sua idade e sexo

Seu peso, altura, índice de massa corpórea.

Sua história gestacional

Sua história clínica relacionada a doenças metabólicas e ósseas

Antecedentes pessoais e familiares de doenças osteometabólicas ou fraturas

Todas as medicações que você usa rotineiramente

Freqüência e tipo de exercício físico.

Frequência de exposição solar

\section{QUEM VERÁ ESTAS INFORMAÇÕES?}

Os investigadores envolvidos no estudo terão acesso as suas informações. O Hospital das Clínicas da Faculdade de Medicina de Ribeirão Preto ou Agencias regulatórias de pesquisa poderão ver partes de seus dados médicos relatados neste estudo e, portanto, verão seu nome ou outras informações de identificação pessoal sobre o (a) seu filho(a). As informações coletas são propriedades do Investigador. No caso de qualquer publicação referente a este estudo, sua identificação não será revelada.

\section{AS INFORMAÇÕES COLETADAS COMO PARTE DESTE ESTUDO SERÃO DESTRUIDAS QUANDO NÃO FOREM MAIS NECESSÁRIAS?}

É difícil para o Investigador saber quanto tempo suas informações serão mantidas, mas comumente elas serão mantidas em banco de dados do Investigador por um período de tempo indefinido. Nós não sabemos quando suas informações não serão mais utilizadas, e não existe uma expiração das informações após elas serem descartadas.

\section{EU POSSO INTERROMPER MINHAS INFORMAÇÕES APÓS ELAS COMEÇAREM A SER UTILIZADAS?}

Se o (a) seu filho (a) deixar o estudo, e não desejar ter mais nenhuma informação pessoal coletada, deverá notificar por escrito ao Dr. Francisco José Albuquerque de Paula, por meio de carta enviada para Av. Bandeirantes, 3900, Monte Alegre, Ribeirão Preto SP. O (a) seu filho(a) poderá também entrar em contato com o Dr. Francisco José Albuquerque de Paula por telefone (16) 36021000. Qualquer informação já coletada continuará a ser vista e usada como descrito previamente.

Declaro ter lido ou terem lido para mim as informações acima antes de assinar o termo de consentimento livre esclarecido. Eu concordo em participar deste estudo clínico. Ainda, eu autorizo que as informações colhidas sejam utilizadas para finalidade da pesquisa proposta. Foime oferecida ampla oportunidade de informação e questionamento bem como recebi todos os esclarecimentos de dúvidas e pontos questionados.

Eu recebi uma cópia deste termo após tê-lo assinado.

\section{Responsável legal}

Nome do responsável legal

Assinatura Responsável legal

Local e data: Ribeirão Preto, 


\section{Testemunhas:}

Nome da testemunha

Assinatura da testemunha

Local e data: Ribeirão Preto,

\section{Pesquisador que obteve o TCLE:}

Nome do pesquisador que obteve o TCLE :

Assinatura do pesquisador que obteve o TCLE:

Local e data: Ribeirão Preto,

\section{Pesquisador Responsável:}

Dr. Francisco José Albuquerque de Paula RG: 545481

Departamento de Clínica Médica, FMRP-USP.

Av. Bandeirantes 3900, Ribeirão Preto, 14049-900, SP, Brasil

Fone: 1636022563

OBSERVAÇÃO: Documento em duas vias, uma para o indivíduo estudado , outra para o pesquisador responsável. 
Anexo 3 : Aprovação do Comitê de Ética em Pesquisa do HCRP e da FMRP-USP

HOSPITAL DAS CLINICAS DA FACULDADE DE MEDICINA DE RIBEIRÃO PRETO DA UNIVERSIDADE DE SÃO PAULO

Ribeirão Preto, 03 de setembro de 2015.

Oficio $n^{\circ} 3138 / 2015$

$\mathrm{CEP} / \mathrm{MGV}$

PROCESSO HCRP $n^{\circ} 4673 / 2015$

Prezados Pesquisadores,

O trabalho intitulado "ASSOCIAÇÃO DO TECIDO ADIPOSO MEDULAR ÓSSEO, MASSA ÓSSEA E AS CONCENTRAÇõEs SÉRICAS DO FATOR DE CRESCIMENTO INSULINA SIMMLE TIPO 1 (IGF-T) E A EXPRESSÃO DO RECEPTOR TIPO 1 DOS FATORES DE CRESCIMENTO INSULINA SÍMILE (IGF1R) EM CRIANÇAS E ADOLESCENTES OBESOS" - Versão 2 datada de 19 de junho de 2015, foi analisado pelo Comitê de Ética em Pesquisa, em sua $414^{\mathrm{a}}$ Reunião Ordinária realizada em 31/08/2015, e enquadrado na categoria: APROVADO, bem como o Termo de Consentimento Livre e Esclarecido Versão 2 datada de 19 de junho de 2015 e o Termo de Assentimento Versão 1 de 19 de junho de 2015.

Atenciosamente.

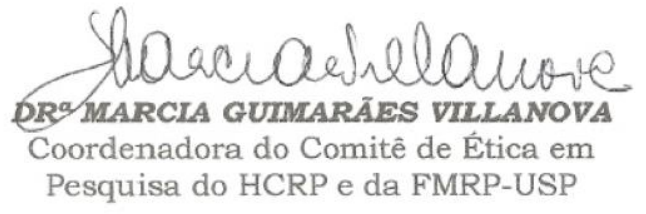

Ilustrissimos Senhores

EMILIANA RIBEIRO DARRIGO

PROF. DR. CARLOS EDUARDO MARTINELLI JUNIOR (Orientador)

Depto. de Puericultura e Pediatria

HOSPITAL DAS CLINICAS DA FACULDADE DE MEDICINA DE RIBEIRÃO PRETO DA UNIVERSIDADE DE SÃO PAULO Campus Universitário - Monte Alegre

Comitê de Ética em Pesquisa do HCRP e FMRP-USP FWA-00002733; IRB-00002186 e 14048-900 Ribeirăo Preto SP 